Kasper Mariusz Kaproń OFMCap, Użycie andyjskiego „aguayo” w liturgii rzymskiej, w: Szata liturgiczna, red. Adelajda Sielepin CHR, Jarosław Superson SAC, Kraków 2016, s. $127-165$.

DOI: http://dx.doi.org/10.15633/9788374386029.08

Kasper Mariusz Kaproń OFMCap

Katolicki Uniwersytet Św. PaWŁa

Cochabamba - Boliwia

\title{
Użycie andyjskiego aguayo w liturgii rzymskiej
}

Zwracając się do biskupów zgromadzonych na II Konferencji Episkopatów Ameryki Łacińskiej i Karaibów w Medellín (I968), ówczesny sekretarz Consilium do wprowadzenia w życie Konstytucji o Liturgii świętej Sacrosanctum Concilium i jeden z głównych architektów soborowej reformy liturgicznej, abp Annibale Bugnini (1912-1982), powiedział m.in.:

Już na samym początku prac Consilium dzieło reformy liturgicznej podzieliliśmy na trzy etapy. W pierwszym okresie nasze wysiłki koncentrować się miały na przejściu w liturgii rzymskiej z języka łacińskiego na języki nowożytne. Etap ten już się zakończył: na całym świecie celebruje się w żywych językach każdego narodu i społeczności. Drugi okres przewidywał opracowanie i publikację nowych ksiąg liturgicznych odnowionych zgodnie z postanowieniami Soboru: prace nad realizacją tego zamierzenia są mocno zaawansowane. Trzeci etap - być może najważniejszy i najbardziej zobowiązujący - ma się dopiero rozpocząć. Dotyczy on adaptacji'.

1 Fragment na podstawie tekstu odbitego na powielaczu, którego kopie otrzymali obecni na Konferencji biskupi. Tekst ten nie znalazł się w oficjalnej publikacji zawierającej dokumentację Konferencji z Medellin. Cytowane za: C. Braga, Adaptación en la Liturgia, „Medellín” I (1975), s. 52. Wcześniej autor zawarł tę samą myśl w: A. Bugnini, Dieci anni, „Notitiae” 9 (1973), s. 395-399; A. Bugnini,, La reforma liturgica conquista la Chiesa, „Notitiae” IO (I974), s. I26. 
Także Jan Paweł II w Liście apostolskim Vicesimus quintus annus ${ }^{2}$ zawarł podobną myśl wskazując, że po dokonaniu wielkiego dzieła, jakim było ofiarowanie ,chrześcijańskiemu ludowi tłumaczeń Pisma Świętego, mszałów i innych ksiąg liturgicznych" (VQA I2) oraz odnowienie obrzędów, pozostaje jeszcze jedno ważne zadanie, jakim jest zakorzenienie liturgii w kulturach:

Pozostaje do wykonania duży wysiłek dalszego zakorzenienia Liturgii w niektórych kulturach, przy jednoczesnym przyjęciu od nich tych elementów, które można pogodzić z prawdziwym i autentycznym duchem Liturgii, z poszanowaniem zasadniczej jedności Obrządku rzymskiego, znajdującej wyraz w księgach liturgicznych (VQA I6).

Adaptacja, a w znaczeniu ścisłym inkulturacja, jest zagadnieniem związanym z reformą i odnową liturgiczną, gdyż ma na celu doprowadzić do pełnego i czynnego udziału wiernych w liturgii (por. KL I4), tak aby poprzez czytelność znaku wierni mogli w sposób bardziej świadomy doświadczyć spotkania z łaską, której nośnikiem jest celebracja Misterium Chrystusa ${ }^{3}$.

Niełatwe, lecz konieczne dzieło adaptacji liturgicznej zostało podjęte na wielu płaszczyznach i z różnym skutkiem przez Kościół latynoamerykański. Wystarczy sięgnąć do dokumentów końcowych Konferencji Generalnych Episkopatów Latynoamerykańskich, aby przekonać się, jak ważny dla tego regionu stał się temat wzajemnych relacji pomiędzy kulturą i ewangelizacją. Stanowił on m.in. przedmiot refleksji biskupów zgromadzonych na IV Konferencji w Santo Domingo (I992). Tematem tej Konferencji była „Nowa ewangelizacja, promocja ludzka i kultura chrześcijańska”, hasłem zaś słowa: „Jezus Chrystus wczoraj, dziś i zawsze”. Natomiast Dokument końcowy Konferencji z Aparecida (2007) ${ }^{4}$, kierując uwagę uczniów misjonarzy na otaczającą ich rzeczywistość, stwierdził: „Jako Kościół biorący na siebie sprawę ubogich zachęcamy ludność rdzenną i afroamerykańską do uczest-

2 Jan Paweł II, List apost. Vicesimus quintus annus w 25. rocznicę ogłoszenia Konstytucji soborowej o Świętej Liturgii Sacrosanctum Concilium (4.I2.1988).

3 Zob. R. González Cougil, La inculturación litúrgica, „Phase” 3I9 (20I4), s. 75-88.

4 Consejo Episkopal Latinoamericano (CELAM), V Conferencia General del Episcopado Latinoamericano y del Caribe, Aparecida, I3-3I de mayo de 2007, wyd. pol.: V Ogólna Konferencja Episkopatów Ameryki Łacińskiej i Karaibów w Aparecida, Dokument końcowy, Gubin 20I4. 
nictwa w życiu eklezjalnym. Z nadzieją patrzymy na proces inkulturacji postrzeganej w świetle Magisterium" (DA 94).

Liturgia, a w szczególności celebracja eucharystyczna, stanowi bez wątpienia uprzywilejowany obszar inkulturacji, jednocześnie jednak ze względu na wyjątkowy charakter świętych czynności inkulturacja nie może być podejmowana w sposób nieprzemyślany, bez dogłębnej oceny i wcześniejszego rozeznania. Celem niniejszego artykułu jest prezentacja $i$ analiza przykładu inkulturacji, jakim jest użycie typowych tkanin indiańskich o bardzo bogatej ornamentyce i kolorystyce (aguayo) do wykonania szat liturgicznych. W pierwszym punkcie przedstawiona zostanie dokumentacja odnoszącą się do kwestii inkulturacji ze szczególnym uwględnieniem szat liturgicznych. Następnie andyjskie aguayo zostanie zaprezentowane jako jedna z najbardziej charakterystycznych tkanin z Ameryki Południowej. Celem tej części jest ukazanie cech charakterystycznych tkaniny oraz przedstawienie zastosowania, jakie posiada ona w kulturze andyjskiej. Nie można zrozumieć znaczenia aguayo bez odniesienia do konkretnych form jego zastosowania w rolnictwie, gospodarce, w życiu rodzinnym oraz w regionalnych wydarzeniach o charakterze społeczno-kulturowym. Ponadto aguayo posiada głęboką wymowę w zależności od zastosowanej kolorystyki, ikonografii i wykończenia. Nie ulega wątpliwości, że jest to tkanina, która wpisała się na stałe w krajobraz andyjski: jest nierozerwalnie związana z widokiem boliwijskiej lub peruwiańskiej kobiety oraz z najważniejszymi wydarzeniami o charakterze wspólnotowym. Na koniec zostanie przedstawione liturgiczne zastosowanie tkaniny. Ze względu na brak wcześniejszych studiów dotyczących liturgicznego użycia aguayo problematyka zostanie przedstawiona na podstawie opinii etnologów, historyków sztuki oraz duchownych, zebranych w indywidualnych rozmowach. Analiza faktu liturgicznego wykorzystania aguayo w kontekście ogólnego zastosowania tej tkaniny pozwoli przedstawić pozytywne i negatywne aspekty tej formy liturgicznej inkulturacji.

\section{NORMY LITURGICZNO-PRAWNE}

Analiza procesu inkulturacji szat liturgicznych wymaga odniesienia do trzech dokumentów: Konstytucji o Liturgii Soboru Watykańskiego II Sacrosanctum 
Concilium (I963) ${ }^{5}$, IV Instrukcji Varietates legitimce (I994) ${ }^{6}$, która w sposób oficjalny interpretuje i aplikuje soborowe wytyczne zawarte w artykułach 3740 Konstytucji o Liturgii ${ }^{7}$ oraz Ogólnego wprowadzenia do Mszału rzymskiego $(2002)^{8}$.

\section{Sacrosanctum Concilium 37-40 (1963)}

Postawowym celem II Soboru Watykańskiego było dostosowanie form przekazu wiary do potrzeb współczesności. Pierwszy dokument Soboru, jakim była KL, już w pierwszym zdaniu odnosi się do tej idei: „Sobór święty postawił sobie za cel: [...] lepiej dostosować do potrzeb naszych czasów podlegające zmianom instytucje". Kwestia właściwie pojętej adaptacji pojawia się zresztą nie tylko na kartach tej Konstytucji, lecz także w konstytucjach Lumen gentium (13, I6, I7) i Gaudium et spes $(42,44,58,9 \mathrm{I})$ oraz w dekrecie Ad gentes (I9.24). We wszystkich tych dokumentach widoczna jest teologiczna i duszpasterska troska, aby przekaz wiary uczynić czytelnym dla współczesnego człowieka i dostosować go właściwie do współczesnej kultury.

KL to „magna charta” liturgicznej adaptacji ${ }^{9}$. W dokumencie tym sa nakreślone ogólne ,zasady dostosowania liturgii do charakteru i tradycji

5 Ogłoszona 4 grudnia I963 roku wraz z motu proprio Sacram liturgiam (25.0I.I964) [dalej: KL].

6 Kongregacja ds. Kultu Bożego i Dyscypliny Sakramentów, Czwarta instrukcja dla poprawnego wprowadzenia soborowej Konstytucji o Liturgii (art. 37-40). Liturgia rzymska i inkulturacja (25.0I.I994) [dalej: VL].

7 Jest to Instructio quarta, która wpisuje się w ciągłość poprzedzających ją instrukcji wykonawczych o tym samym charakterze i opublikowanych w celach prawidłowej aplikacji KL. Tymi instrukcjami są: pierwsza Inter oecumenici (26.09.1964); druga Tres ab hinc annos (4.05.1967) i trzecia Liturgicae instaurationes (5.09.1970). 28 marca 200I została opublikowana piąta instrukcja wykonawcza Liturgiam authenticam.

8 Missale Romanum ex decreto Sacrosancti Oecumenici concilii Vaticani II instauratum, auctoritate Pauli pp. VI promulgatum, Ioannis Pauli pp. II cura recognitum, Editio typica tercia, typis Vaticanis MMII.

9 Sformułowanie to zostało użyte przez Pawła VI w przemówieniu wygłoszonym do Consilium Io kwietnia I970 w odniesieniu do reformy liturgicznej. Zob. Enchiridion, I. n. 2073. Tego samego wyrażenia, jednakże w odniesieniu do adaptacji liturgicznej, użył Anscaro Chupungco w The Magna Charta of Liturgical Adaptation, „Notitiae” I4 (I978), s. 75; A. Chupungco, Cultural Adaptation of the Liturgy, New York I982, s. 42. 
narodów" (art. 37-40) ${ }^{\mathrm{IO}}$. W tej części soborowego dokumentu przedstawione są: a) KL 37: zasady ogólne adaptacji; b) KL 38-39: kwestia uprawnionych różnic istniejących w obrządku rzymskim; c) KL 40: ogólne zasady „głębszego dostosowania liturgii".

W artykule 37 zostaje potwierdzone istnienie w Kościele, a szczególnie w liturgii, różnorodności w tych wszystkich aspektach, które nie naruszają jedności w wierze lub też dobra całej wspólnoty. Artykuł stwierdza, że Kościół z wielkim szacunkiem odnosi się do kultury plemion i narodów, i że w niektórych przypadkach akceptuje niektóre z elementów kultury w liturgii, jeżeli tylko odpowiadają one ,zasadom prawdziwego i autentycznego ducha liturgicznego".

Artykuły 38-39 omawiają kwestię uprawnionych różnic w liturgii rzymskiej, które są dopuszczalne pod warunkiem, że zostanie zachowana ,istotowa jedność obrządku rzymskiego". Jak można wywnioskować z treści art. 39, ta istotowa jedność ${ }^{I I}$ zostaje zagwarantowana, jeżeli nie wykracza się poza granice ustalone ,przez wzorcowe wydania ksiąg liturgicznych”"2.

10 Szczegółowy komentarz do KL 37-40 można znaleźć m.in. w: A. Chupungco, Cultural Adaptation..., dz. cyt., s. 42-57; A. Chupungco, Adaptación de la liturgia a la cultura y tradiciones de los pueblos, „Phase” I47 (I985), s. 230-232; A. Chupungco, Adaptación de la liturgia a la cultura y tradiciones de los pueblos. L'adattamento della liturgia dei sacramenti: principi e possibilità, „Anàmnesis” 3/I La Liturgia. I sacramenti: teologia e storia della celebrazione, Genova 1986, s. 369-371; A. Chupungco, Liturgies of the Future. The process and Methods of Acculturation, New York 1989, s. 8-18. Godny polecenia jest także: Sacrosanctum Concilium - „Inter mirifica”. Commento ai Documenti del Vaticano II, red. S. Nocetie, R. Repole, Bologna 20I4, s. I6I-I66.

11 Zob. B. Neunheuser, Servata substantiali unitate ritus romani: SC 38, „Ecclesia Orans” 8 (199I) nr I, s. 77-95.

12 W księgach tych Stolica Apostolska wskazuje na elementy, które konferencje episkopatów mogą w sposób wolny zmodyfikować i które po uzyskaniu aprobaty odpowiedniej instancji rzymskiej mogą być wprowadzone do oficjalnego tekstu ksiąg używanych w Kościele lokalnym. Wprowadzone modyfikacje nie naruszają istotowej jedności liturgii rzymskiej, a jedynie dają jej konieczną elestyczność, aby mogła pełniej odpowiedzieć na lokalne zapotrzebowania, szczególnie w krajach misyjnych. Dotyczy to przede wszystkim „sprawowania sakramentów, sakramentaliów, procesji, języka liturgicznego, muzyki i sztuki kościelnej”. Należy dodać do tej listy także liturgię godzin i rok liturgiczny, zgodnie z tym, co zostało określone w art. 88 odnośnie do Boskiego Oficjum i w artykułach I07 i IIo odnośnie do roku liturgicznego. 
Artykuł 40 omawia zagadnienie konieczności „głębszego dostosowania liturgii" ${ }^{\prime \prime}$, tzn. zmian bardziej radykalnych, idących znacznie dalej niż te prawnie usankcjonowane i sugerowane $\mathrm{w}$ wydaniach typicznych ksiąg liturgicznych. Zmiany te implikują radykalną adaptację liturgii.

José Aldazábal zreasumował powyższe punkty KL w następujących słowach:

dokument o liturgii wskazał na dwie zasadnicze kwestie [...] jedność i różnorodność. Poprzez rozróżnienia na elementy nie podlegające zmianom i te które są zmienne (KL 2I), wskazując na konieczność dokonania zmian organicznych, poprzedzonych poważnymi studiami (KL 23), zostaje zdefiniowana, przeciwko sztywnej jednolitości, zasada pluralizmu. Stawiając jako warunek zachowanie jedności wiary i mając zawsze na uwadze dobro całej wspólnoty Kościoła, sformułowano zasadę poszanowania dla geniuszu narodów i unikalnych cech każdego ludu i kultury, propagując rozwój studiów i dbając o pielęgnowanie tych tradycji, które mogą być zasymilowane przez liturgię chrześcijańską bez zagubienia jej bogactwa i tożsamości (KL 37). Zmiany i adaptacje, także dotykające struktury, muszą jednak gwarantować „strukturalną jedność obrządku rzymskiego" (KL 38), która zostaje zabezpieczona przez wierność wzorcowym wydaniom ksiąg liturgicznych (KL 39). Jednocześnie zostawia się otwartą drogę, w art. 40, głębszym adaptacjom, powierzając troskę i odpowiedzialność w tej materii konferencjom biskupów ${ }^{\mathrm{I}}$.

Krajowym konferencjom biskupów zostało też powierzone zadanie przystosowania wszystkich rzeczy materialnych związanych z kultem, w tym także tego, co odnosi się do „materiału oraz kształtu sprzętów i szat ko-

13 Pierwotny zapis artykułu wskazywał bezpośrednio na potrzeby ludności z terytoriów misyjnych. Jednakże ojcowie soborowi zwrócili uwagę, że także niektóre kraje Europy mogą być uznane jako obszar misyjny. Stąd też komisja soborowa postanowiła wyeliminować z ostatecznej wersji artykułu określenie „terytoria misyjne”. W konsekwencji kwestia głębszego dostosowania liturgii dotyczy nie tylko Kościołów misyjnych znajdujących się na obszarach Trzeciego Świata. Por. Schema Constitutionis De Sacra Liturgia: emendationes IV, Città del Vaticano 1963, s. I6. Relator komisji Camille Callewaert wythumaczył tę kwestię w następujacych słowach: „Ex Patribus alii quoque contendebant eo suppremendam ese mentionem de Missionibus, quod eaedam conditiones alibi easdem solutiones postulent; sed cum dicitur «praesertium», clare indicatur Missiones non esse solas regiones in quibus aptatio necessaria evadat". Cytowane za: A. Chupungco, Liturgies of the Future. The Process and Methods of Inculturation, New York I989, s. 48.

14 J. Aldazábal, Lecciones de la historia sobre la inculturación, „Phase” 206 (I995), s. IOI. 
ścielnych”, przez dostosowanie ich do „miejscowych potrzeb i zwyczajów”. Wytyczne te zostały zawarte w art. I28, który to artykuł odsyła jednocześnie do ogólnych zasad dotyczących odnowy liturgii (art. 22-25).

\section{Instrukcja Varietates legitimce (1994)}

Opublikowany przez Kongregację Kultu Bożego i Dyscypliny Sakramentów dokument Liturgia rzymska i inkulturacja. Instrukcja dla poprawnego wprowadzenia soborowej Konstytucji o Liturgii (art. 37-40) jest kolejnym krokiem wytyczającym szlak Kościoła w procesie inkulturacji liturgicznej ${ }^{15}$.

Dokument formułuje zasady doktrynalne oraz określa praktyczne kryteria adaptacji mające na celu wdrożenie wiernych do pełnego, świadomego i czynnego udziału w obrzędach liturgicznych ${ }^{16}$. IV Instrukcja przyjmując w art. 4 i 5 termin ,inkulturacja” jako ten, który o wiele lepiej niż ,,adaptacja”, oddaje złożoność procesu wcielenia wiary w kulturę, definiuje to pojęcie jako proces ,wcielenia Ewangelii w kultury miejscowe, a jednocześnie wprowadzenia tychże kultur do życia Kościoła" (VL 4) ${ }^{17}$.

Inkulturacja zakłada wzajemne oddziaływanie na siebie, współzależność: Kościół użyźnia określone środowisko społeczno-kulturowe bogactwem

15 Por. A. Chupungco, Cultural Adaptation of the Liturgy..., dz. cyt.; A. Chupungco, Liturgies of the Future..., dz. cyt.; A. Chupungco, Inculturacione e liturgia: i termini del problema, „Rivista Liturgica” 4 (1995), s. 36I-385; A. Chupungco, „A Definition of Liturgical Inculturation”, „Ecclesia Orans” 5 (1988), s. II-23; L'adattamento culturale della liturgia. Metodi e modelli. Atti del IV Congresso Internazionale di Liturgia: Roma, Pontificio Istituto Liturgico, 6-Io Maggio I99I, ed. I. Scicolone, Roma I993 (Studia Anselmiana, II3); J. Evenou, La IV Instruzione per una corretta applicazione della Costituzione conciliar sulla Liturgia (nn. 36-40). Presentazione, „Rivista Liturgica” 4 (1995), s. 386-40I; A. M. Triacca, „Princi$p i$-fondamenti teológico-liturgici emergente dalla IV Istruzione, „Rivista Liturgica” 4 (I995), S. 402-420; J. Aldazábal, Lecciones de la historia sobre la inculturación, „Phase” 206 (I995), s. IOI.

16 Instrukcja, oprócz Wprowadzenia (nry I-8), podzielona jest na cztery części: Pierwsza z nich (nry 9-20) przedstawia „Proces inkulturacji w historii zbawienia”. Część druga zatytułowana jest: Wymagania i warunki wstępne dla inkulturacji liturgicznej" (nry 2I-32). Trzecia część określa „Zasady i normy praktyczne dla inkulturacji obrządku rzymskiego” (nry 33-5I). Czwarta część definiuje „Zakres adaptacji w obrządku rzymskim” (nry 52-69). Całość dokumentu zamyka Zakończenie ( $\mathrm{nr} 70$ ).

17 IV Instrukcja przywołuje słowa Jana Pawła II zawarte w encyklice Redemptoris missio (7 XII 1990) nr 52, gdzie w sposób bardzo klarowny papież mówi o podwójnym oddziaływaniu, jakie zakłada inkulturacja. 
Ewangelii i jednocześnie przyswaja sobie wartości kulturowe tego środowiska pod warunkiem, że są one zgodne z Ewangelią. Ta obustronna relacja sprawia, że orędzie Chrystusa może być rozpowszechniane i przyswajane z większą skutecznością (por. VL 4).

Inkulturacja realizuje $\mathrm{w}$ ten sposób jedno $\mathrm{z}$ najważniejszych postulatów KL, jakim jest „troska o odnowienie i rozwój liturgii” (KL I, 2I), i pozwala ukonkretnić trzeci etap reformy ${ }^{18}$. Myśl tę IV Instrukcja, wskazując na ostateczny cel inkulturacji liturgicznej, wyraża w następujący sposób:

Celowość, która powinna kierować inkulturacją obrządku rzymskiego, jest ta sama, jaką II Sobór Watykański położył u podstaw ogólnej odnowy Liturgii: „To odnowienie ma polegać na takim układzie tekstów i obrzędów, aby one jaśniej wyrażały święte tajemnice, których są znakiem, i aby wierni chrześcijanie, o ile to możliwe, łatwo mogli je zrozumieć i uczestniczyć w nich w sposób pełny, czynny i zbiorowy"(VL 35).

Dokument ten został opracowany z wielką precyzją teologiczną; jego język odznacza się wielką dbałością o szczegóły i wyrazistością. Przed ogłoszeniem został przekazany do analizy kilku dykasteriom Kurii rzymskiej. Jest to tekst podstawowy i obowiązkowy dla wszystkich, którzy podejmują prace w zakresie inkulturacji liturgicznej ${ }^{19}$.

Instrukcja odnosząc się do inkulturacji celebracji liturgicznej wskazuje, że w procesie tym należy brać pod uwagę zarówno ,zawartość teologiczną”, jak i „formę liturgiczną”, gdzie ta druga ma być rozumiana jako

18 Warto w przywołać następujące słowa A. Chupungco: „Planowany powrót do formy klasycznej liturgii rzymskiej (reforma liturgiczna) widziany był [przez Ojców soborowych] jako najlepszy sposób do wdrożenia wiernych w uczestnictwo świadome i aktywne. Był postrzegany także jako niezbędny warunek późniejszego zaadaptowania liturgii w różnorodnych kulturach współczesnych, na wzór wspólnot franko-germańskich, które zaadaptowały liturgię rzymską klasyczną i kulturę rzymską. Projekt KL powinien być zatem analizowany w świetle postulatów Soboru, czyli pobudzenia aktywnego uczestnictwa oraz otwarcia bram dla adaptacji kulturowej”, w: A. Chupungco, Adaptación de la liturgia...dz. cyt, s. 230. Por. A. Chupungco, Liturgies of the Future..., dz. cyt., s. 6.

19 Zob. J. M. Canals, Las adaptaciones que competen a los Obispos. Un nuevo capitulo en la „Institutio” de la tercera edición del Misal Romano, „Phase” 266-267 (2005), s. I79. 
zewnętrzne, widzialne wyrażenie zawartości teologicznej. Art. 43 Instrukcji jest klarowny:

Obrzędy liturgiczne ubogaca wkład sztuki, która pomaga wiernym w ich sprawowaniu, w spotkaniu z Bogiem i modlitwie. Sztuka powinna więc posiadać w Kościele każdego ludu i narodu wolność wyrazu, uwzględniwszy, by przyczyniała się do piękna budowli i obrzędów liturgicznych przez szacunek i cześć, jakie są im należne, oraz by miała rzeczywiście znaczącą rolę w życiu $\mathrm{i}$ tradycji narodu. To samo dotyczy formy, ustawienia i ozdoby ołtarza, miejsca głoszenia Słowa Bożego i udzielania Chrztu, sprzętów, naczyń, szat i kolorów liturgicznych. Powinno się dać pierwszeństwo materiałom, formom i kolorom bliskim danemu krajowi.

W tekście tym została poruszona kwestia inkulturacji elementów należących do sztuki sakralnej i będących w służbie liturgii. Pośród licznych form artystycznego wyrazu, takich jak architektura kościołów i wystrój przestrzeni liturgicznej, dokument wymienia także szaty liturgiczne. Szaty, tak jak inne elementy sztuki sakralnej, należą do form zewnętrznych, które powinny być brane pod uwagę w inkulturacji. Zadaniem artystów jest, aby oddawały one w sposób jak najbardziej wierny partykularne i charakterystyczne cechy danej kultury, a jednocześnie były wyrazem piękna: „Piękności Odwiecznej, a zawsze nowej" ${ }^{20}$.

Dlatego też w procesie inkulturacji szat liturgicznych ,powinno się dać pierwszeństwo materiałom, formom i kolorom bliskim danemu krajowi”. Odnośnie do szat liturgicznych Instrukcja w art. 54 przywołuje zasady i normy zawarte w Mszale rzymskim, które przewidują, zgodnie z Konstytucją o świętej Liturgii, że „Konferencje Episkopatu dla podległych sobie obszarów mogą ustalać przepisy, uwzględniając tradycje i charakterystyki ludów, krajów i różnych grup". Dotyczy to m.in. form i kolorów szat liturgicznych.

\section{Ogólne wprowadzenie do Mszału rzymskiego. Wydanie trzecie wzorcowe (2002)}

Największą nowością Ogólnego wprowadzenia do Mszału rzymskiego, trzecie wydanie wzorcowe, jest wprowadzenie nowego rozdziału (dziewiątego):

20 Zob. św. Augustyn, Wyznania, X, 27. 
Adaptacje zależne od kompetencji biskupów oraz konferencji episkopatu. Odpowiada on rozdziałom, które znajdują się w Praenotanda innych ksiąg liturgicznych zreformowanych po Soborze, gdzie omawia się uprawnienia konferencji episkopatu oraz biskupów w zakresie adaptacji w ramach poszczególnych sakramentów. We wcześniejszych edycjach wzorcowych nie bylo tego rozdzialu ${ }^{21}$.

Rozdział IX można podzielić na dwie części: kompetencje biskupa diecezjalnego (nr 387) i kompetencje konferencji episkopatu (nry 388-399). Całość poprzedza nr 386 będący wprowadzeniem, w którym wskazano na fundament teologiczny i prawny całego rozdziału. Zostało przypomniane, że podstawa normatywna adaptacji i inkulturacji liturgii mszy wynika z założeń reformy liturgicznej zawartych w soborowej Konstytucji o Liturgii, „aby wszyscy wierni w celebrację Eucharystii wnosili pełny, świadomy i czynny udział" (por. KL I4). Zasada ta uprawomocnia działania na rzecz adaptacji. Inkulturacja w liturgii Mszy świętej nie jest więc celem samym w sobie, lecz wynika z racji duszpasterskich.

Pośród kompetencji należących do konferencji episkopatu (nry 388-399), to znaczy tych, które wymagają szerszej koordynacji i nie mogą być podjęte indywidualnie przez biskupa diecezjalnego, dokument wymienia możliwość adaptacji w zakresie: „tworzywa, z jakiego ma być budowany ołtarz oraz przedmioty wyposażenia kościoła, zwłaszcza naczynia liturgiczne, a także materiał, krój i kolor szat liturgicznych" (nr 390). Dokument jednocześnie przywołuje wcześniejsze przepisy zawarte w nr. 342-346, a dotyczące bezpośrednio szat liturgicznych.

Przepisy zawarte w rozdziale VI OWMR, omawiającym „rzeczy potrzebne do sprawowania mszy świętej”, już same w sobie dopuszczają możliwość

21 Zob. A. Word, Features and Significance of the New Chapter of the „Instituto Generalis Missalis Romani”, „Ephemerides Liturgicae” II4 (2000), s. 498-5I0; M. Barba, La nuova Institutio Generalis del Missale Romanum, „Rivista Liturgica” 90 (2003), s. 513-532; M. Augé, Il capitolo IX dell 'Institutio Generalis: tra adattamento e inculturazione, „Rivista Liturgica” 90 (2003), s. 533-547; M. Sodi, A. Toniolo, Praenotanda Missalis Romani, textus - concordantia - appendices, editio typica tertia, Città del Vaticano 2003; J. M. Canals, Las adaptaciones que competen a los Obispos. Un nuevo capitulo en la "Institutio” de la tercera edición del Misal Romano, „Phase” 266-267 (2005), s. I69-179; R. González Cougil, Ordenación General del Misal Romano (2002). Comentario (IX). Las adaptaciones que competen a los obispos y a sus conferencias (nn. 386-399), „Pastoral Litúrgica” 288 (2005), s. 294-315; R. Falsini, A. Lameri, Ordinamento Generale del Messale Romano. Comento e texto, Padova 2006, s. 98-I02; R. Russo, Institución General del Misal Romano. Textos. Estudios, Montevideo 2009, s. 213-217. 
adaptacji kształtu szat liturgicznych do potrzeb i zwyczajów poszczególnych krajów (nr 342) i omawiają kwestię użycia tkanin właściwych danemu krajowi (nr 343). Należy jednak pamietać, że decyzje w tej sprawie należą do konferencji episkopatu i muszą być zatwierdzone przez Stolicę Apostolską. Zezwala się na wykorzystanie ozdób figuralnych i symboli właściwych danej kulturze, z zastrzeżeniem, że znaki te mają wskazywać na sakralne zastosowanie tych szat, czyli nie można używać ornamentyki, która nie przystoi ich sakralnemu przeznaczeniu (nr 344). Odnośnie do kolorystyki szat liturgicznych dokument zaleca użycie kolorów liturgicznych zgodnie z wielowiekową tradycją, jednocześnie jednak postanawia, że „w odniesieniu do kolorów liturgicznych konferencje episkopatów mogą ustalić i przedstawić Stolicy Apostolskiej inne zasady, które by lepiej odpowiadały potrzebom i duchowi poszczególnych narodów" (nr 346).

Jako podsumowanie zaprezentowanych dokumentów możemy stwierdzić, że:

inkulturacja liturgiczna z perspektywy liturgii może być zdefiniowana jako „proces wkomponowania tekstów i obrzędów liturgicznych w strukturę kultury lokalnej". Teksty, obrzędy, gesty itd. asymilują myśl ludu, jego język, jego wartości, symbole, sztukę (architekturę, muzykę, rzeźbę, malarstwo, ornamentykę i dekorację), to znaczy całość dziedzictwa kulturowego ludu. Inkulturacja liturgiczna jest więc asymilacją elementów kultury lokalnej. W wyniku tego procesu liturgia i kultura wzajemnie się przenikają w przestrzeni myśli, języka i obrzędu. Liturgia myśli (Pismo Święte i euchologia - wiara głoszona i celebrowana), mówi (przekaz werbalny: słowa, śpiew, milczenie, i pozawerbalny: gesty) i celebruje (tworzy świat gestów i rytów), wykorzystując do tego elementy kultury Kościoła lokalnego ${ }^{22}$.

\section{TKANINY W KULTURZE ANDYJSKIEJ: SYMBOLIKA I UŻYCIE TKANIN O TYSIĄCLETNIEJ TRADYCJI}

Tkaniny tworzone w społecznościach zamieszkujących Płaskowyż Andyjski są produktami artystycznymi o wyjątkowych znaczeniu. Nie tylko spełnia-

22 R. González Cougil, La inculturación litúrgica, „Phase” 3I9 (20I4), s. 79-80. 
ją określoną funkcję użytkową, ale ponadto są sposobem przekazu informacji o charakterze społeczno-kulturowym i religijnym, określają rolę, jaką dana osoba pełni w strukturze społecznej oraz przedstawiają historię danej wspólnoty. Ich użycie wiąże się ściśle z cyklem życia ludzkiego, wykorzystywane są w ważnych sytuacjach egzystencjalnych (narodziny, małżeństwo, śmierć), określają tożsamość jednostki w grupie społecznej. W tym sensie tkanina w społeczność andyjskiej jest czymś więcej niż materiałem służącym do wykonania okrycia: jest sposobem komunikowania się ze światem i jednym z najbardziej złożonych sposobów ekspresji o dużych wartościach estetycznych. Jest to sztuka o tysiącletniej historii: w ciągu wieków różne grupy etniczne, bazując na dostępnych włóknach naturalnych, za pomocą kolorów i wzorów wytworzyły skomplikowany system znaków, który stał się prawdziwym językiem, poprzez który społeczności identyfikują się i ukazują swoją różnorodność.

Płaskowyż Andyjski tworzy naturalny obszar geograficzno-kulturowy obejmujący część powierzchni następujących krajów: Peru, Ekwadoru, Chile, Argentyny i Boliwii. Na tym obszarze ludność udomowiła cztery rodzaje zwierząt należących do wspólnej grupy wielbłądowatych: lama (Lama Glama), gwanako (Lama Guanicoe), alpaka (Lama Glama Pacas) i wikunia (Vicugna Vicugna), których wełna od wieków służy do wytwarzania okryć koniecznych do funkcjonowania w mroźnym klimacie Andów. W dolinach natomiast uprawiano bawełnę (Gossypium barbadense), której obróbkę znano na długo przez przybyciem na te tereny Europejczyków. Z owadów z rodziny pluskwiaków (Coccus cacti) żyjących na kaktusie koszenilowym (Nopalea cochenillifera L.), rosnącym dziko w całej Ameryce, uzyskuje się trwały naturalny barwnik, który daje, w zależności od stężenia, kolory od czerwieni, poprzez fiolet, aż do czerni. Korzeń rośliny Relbunium pozwala uzyskać kolory w odcieniach niebieskiego.

Bardzo prężny rozwój kultury tkackiej na obszarze imperium Inków, o czym zaświadcza m.in. rękopiśmienny dokument autorstwa Poma de Ayala El Primer Nueva Crónica y Buen Gobierno z ok. I6I4²3, załamał się wraz z przybyciem na te tereny hiszpańskich konkwistadorów. Dokonała się zmiana systemu tkackiego wskutek wprowadzenia nowych włókien, takich jak wełna owcza, len i jedwab. Wprowadzono zmiany w systemie tkackim poprzez zastosowanie nowych urządzeń i nowych sposobów wyko-

${ }^{23}$ G. Poma De Ayala, La Nueva Crónica y Buen Gobierno (I6I4), wyd. faksymile, La Paz 20I5. 
nywania tkanin. Nastąpiła zmiana w ornamentyce poprzez wprowadzenie nowych wzorów bazujących na wzorach arabskich dywanów. Powstał nowy styl, zwany andyjsko-kolonialnym, będący połączeniem elementów dwóch tradycji.

Pomimo bardzo silnej akulturacji tradycyjna sztuka tkacka jest kultywowana do naszych czasów dzięki rdzennej ludności indiańskiej, która przeniosła się w trudno dostępne obszary górskie. Dla miejscowej ludności kolorystyka i wzornictwo tkanin jest systemem znaków, poprzez który przekazuje się informacje dotyczace tożsamości społecznej, regionalnej, a nawet płciowej. Tkaniny służą wyrażaniu cech indywidualnych i wspólnotowych, określają status społeczny osób, ich wiek, stan cywilny, pełnioną funkcję. Tkaniny z regionu Andów są syntezą przeszłości i teraźniejszości, użyteczności i symboliki, techniki i estetyki. Bogactwo symboliki i wyjątkowe piękno tkanin wywarły wielkie wrażenie i olśniły pierwszych kolonizatorów, a dzisiaj przyciągają turystów przybywających na te tereny. Andyjskie rzemiosło tkackie ukształtowało autentyczną tradycję o tysiącletnim rodowodzie i charakterystyce wyodrębniającej ją spośród sztuki tekstylnej reszty świata.

Od kilkudziesięciu lat andyjska sztuka tekstylna stanowi przedmiot zainteresowań licznych naukowców ${ }^{24}$. Jest analizowana przez archeologów,

24 D. Y. Arnold, Hilos sueltos: los Andes desde el textil, La Paz 2007; E. J. Fortun, Artesanía Popular, La Paz 196r; T. Gisbert, S. Arze, M. Cajías, Arte textil y mundo andino, La Paz 2006; Museo Nacional de Etnografía y Folklore, Textiles de las naciones y pueblos originarios, La Paz 1993; J. Sagarnaga, Diccionario de la cultura nativa en Bolivia, La Paz 2003; S. Rivera Cusicanqui, D. Y. Arnold, Z. Lehm, Ser mujer indigena, chola o birlocha en la Bolivia postcolonial de los años 90, La Paz 1996; X. Medinaceli, Mujeres en las ciudades de Bolivia. 1920-1930, La Paz 1989; D. Y. Arnold, Convertirse en persona el tejido: la terminología aymara de un cuerpo textil, w:, Actas de la I Jornada Internacional sobre Textiles Precolombinos, red. V. Solanilla, Barcelona 2000; A. G. Cook, The Emperor's new clothes: symbols of royalty, hierarchy and identity, „Journal of the Steward Anthropological Society" 24 (1996), s. 85-I20; A. Cordy-Collins, Telas pintadas Chavín del valle de Ica, Costa Sur / Painted Chavin Textiles from Ica valley, South Coast, J. A. Lavalle, R. De Lavalle, Tejidos milenarios del Perú / Ancient Peruvian Textiles, Lima 1999, s. I07-I42; S. Desrosiers, Las técnicas de tejido ¿tienen un sentido? Una propuesta de lectura de los tejidos andinos, „Revista Andina” I9 (1992), s. 7-46; P. Eeckout, N. Danis, Los tocapus reales en los dibujos de Guamán Poma: una heráldica incaica?, Actas del IV Simposio Internacional de Arqueología de la Pontificia Universidad Católica del Perú, Lima 2002, s. 37-58; E. Franquemont, The true tresure of andean textiles, w: Traditional Textiles of the Andes. Life and cloth in the Highlands, red. L. Meisch, Nueva York 1996, s. 38-47; I. Iriarte, Tapices con escenas biblicas del Perú Colonial, „Revista Andina” 19 (1992), s. 80-I05; J. Pillsbury, Inka Unku: Strategy 
etnologów, antropologów. Istnieje bardzo dużo prac naukowych i popularyzatorskich w zakresie rękodzieła tekstylnego w kulturze andyjskiej, analizujących przedmiot badań pod kątem historycznym, typologii używanych tkanin, ornamentyki itd. Tkaniny wytwarzane są w wielu regionach, stąd też badacze skoncentrowali poszukiwania na wzajemnych oddziaływaniach kultury lokalnej i symboliki tkanin, wyodrębniając cechy partykularne tkanin w zależności od miejsca ich wytwarzania. Rozwój rękodzieła tkackiego stanowi popularny temat prac badawczych, gdyż pozwala zaobserwować zachodzące zmiany w zakresie życia społecznego i religijnego poszczególnych społeczności andyjskich.

Cechą tych tkanin jest ich szeroki zakres wykorzystania i wielofunkcyjność. Używane są one jako ubiór i nakrycia wierzchnie, zarówno w dni powszednie, jak i podczas świąt. Odgrywają ważną rolę w rolnictwie, np. przy zasiewie lub oznaczaniu bydła, co sprawia, że stają się elementem kultury religijnej skoncentrowanej na kulcie Matki Ziemi. Tkaniny wykorzystywane są do noszenia dzieci i transportu produktów rolnych, używa się ich w czasie uroczystości o charakterze rodzinnym, jak np. zawarcie małżeństwa czy pierwsze postrzyżyny dziecka. Pełnią określoną rolę w czasie spotkań lokalnych władz, gdy podejmowane są ważne dla społeczności decyzje, są wykorzystywane przy przekazywaniu insygnów władzy itd. Już samo to wyliczenie wskazuje na różnorodne zastosowanie tkanin, a wszystkie te formy zastosowania podkreślają ich charakter religijny, gdyż w świadomości ludów zamieszkujących Andy zarówno uprawa roli, jak i ważne wydarzenia z życia społecznego i indywidualnego są za-

and desing in Colonial Peru, Lima 2002; G. Silverman, El tejido Andino: un libro de sabidurí, Lima 1994; R. Stone-Miller, Middle Horizon Textiles in the Museum of Fine Arts, Boston I992; J. Woutiers, N. R. Chirinos, Los secretos de los tintoreros andinos. Íconos, „Revista peruana de conservación, arte y arqueología" I (1999), s. 38-45; T. Abercrombie, Pathways of Memory and Power. Ethnography and History Among an Andean People, Madison y London 1998; A. Appadurai, The Social Life of Things: Commodities in Cultural Perspective, Cambridge 1999; M. Augé, Mestizo Spaces. An Anthropology for Contemporaneous Worlds, Stanford I999; V. Cereceda, Sémiologie des tissus andines, „Annales” 33 (1978), s. IOI7-I036; V. Cereceda, Semiología de los textiles andinos: las talegas de Isluga, „Chungara. Revista de Antropología Chilena" 42 (2010), s. I8I-198; E. Fischer, Herstellung und Verwendung in musterbildender Kettentechnik gefertigter Textilien der Region Charazani am Beispiel der Dorfgemeinschaft Upinhuaya. Weberei und Gesellschaft andiner Regionen Boliviens, Viena I999; ; E. Fischer, Urdiendo el Tejido Social. Sociedad y Producción Textil en los Andes bolivianos, Viena 2007; L. Girault, Textiles Boliviens. Région de Charazani, Paris I969; J. Izko, Comunidad andina: Persistencia y cambio, ,Revista Andina” 7 (I986), s. 59-99. 
wsze wydarzeniami o charakterze religijnym. Dlatego też analiza i prace badawcze na temat tkanin w kulturze andyjskiej siłą rzeczy ukierunkowują poszukiwania na świat wierzeń Indian Aymara i Quechua.

Podstawową formą zastosowania tkanin jest oczywiście produkcja ubrań i części odzieży. Opis poszczególnych części garderoby wraz z ich nazwami w języku aymara można znaleźć w jednym z najstarszych słowników języka aymara autorstwa Ludovica Bertonia ${ }^{25}$. I tak np. isallo, isacayo lub lliclla były rodzajem wierzchniego okrycia $\mathrm{w}$ formie płaszcza; medio acsu pełniła funkcję spódnicy; hamacora była okryciem kobiet należących do arystokracji inkaskiej; uncuña lub tari były chustkami używanymi do przechowywania w nich liści koki; urco, acsu lub saya - prostokątną tkaniną używaną przez kobiety celem ochrony przez zimnem; aguayo - prostokatną tkaniną służącą do noszenia dzieci na plecach; huaka lub chumpi były rodzajem pasa używanego przez kobiety; histalla lub chusoa pełniły funkcje torby do przechowywania drobnych rzeczy.

W naszej analizie celowo zostaną pominięte części ubioru, skoncentrujemy się na aguayo . Ta najbardziej charakterystyczna tkanina Płaskowyżu Andyjskiego, oryginalnie wykorzystywana w praktykach religijnych, wraz ze zmieniającą się strukturą społeczno-ekonomiczną miejscowej populacji przeszła dość złożoną ewolucję i używana jest obecnie m.in. do wyrobu szat liturgicznych.

\section{Aguayo - tkanina określająca tożsamość}

Archeolog Jedú Sagárnaga zdefiniował awayu, ahuayo lub jawayu jako „różnokolorową prostokątną tkaninę obecnie wytwarzaną najczęściej z wełny owczej. Przeznaczona jest do noszenia na plecach dzieci i przedmiotów"26. Tkanina ta posiada bogate znaczenie symboliczne, gdyż wyraża przestrzeń życia Indian Aymara y Quechua: pampa (otwarta przestrzeń wyrażona przez główny kolor tkaniny) i pallay (obszary uprawne, pasy gleby tworzące się podczas orania, wyrażone przez różnokolorowe linie proste) ${ }^{27}$. Teresa Gisbert, historyk i etnograf specjalizująca się w kulturach andyjskich, opierając się

25 L. Bertonio, Transcripción del Vocabulario de la lengua Aymara I6I2, La Paz 1993.

26 J. Sagarnaga, Diccionario..., dz. cyt., s. 7I.

$27 \quad$ J. Sagarnaga, Diccionario..., dz. cyt., 7I. 
na Vocabulario de la Lengua Aymara autorstwa Ludovica Bertonia, definiuje aguayo jako:

chustę, która służy do noszenia dziecka na plecach o wymiarach większych w porównaniu do lliclla i podobnia jak ta ostatnia tworzy się ją poprzez zszycie dwóch identycznych kawałków tkanin. Typowe aguayo Aymara z regionu La Paz posiada wzór oparty na różnokolorowych liniach przeplatanych szerokimi pasami pampy. Andyjskie aguayo posiadają ściśle określone motywy dekoracyjne, w tym także dekoracje w formie liter tworzących napisy ${ }^{28}$.

Aguayo jako element życia społecznego pełni wielorakie funkcje użytkowe. Opierając się na pracach Luz Castillo, można dokonać ogólnej klasyfikacji według zmian zachodzących w produkcji aguayo, konsekwencji przeobrażeń w strukturach społecznych i gospodarczych regionu ${ }^{29}$ :

a) Ch'ankha awayu: aguayo tkane ręcznie $\mathrm{z}$ wełny alpaki lub wikuni, o bardzo dużym znaczeniu symbolicznym. Wełna do wykonania tego typu aguayo jest barwiona wyłącznie przy użyciu barwników pochodzenia naturalnego, stąd kolorystyka stonowana. Ten typ aguayo dominował w okresie przedkolumbijskim; do dzisiaj konfekcjonowany jest w andyjskich wspólnotach i wioskach zamieszkałych przez rdzenną ludność Aymara. Wykorzystywane jest głównie w obrzędach o charakterze religijnym.

b) Lana awayu: aguayo wykonane z wełny owczej lub bawełny, najczęściej tkane ręcznie. Ten typ posiada żywą kolorystykę i wyodrębnił się na drodze przemian społecznych, kiedy to ludność metyska zdominowała handel. Jest to najbardziej rozpowszechniony typ aguayo, wykorzystywany do noszenia dzieci i produktów. Wykonywane z bawełny, jako lżejsze wykorzystywane jest do dekoracji strojów folklorystycznych.

c) Ilu awayu: aguayo wytwarzane obecnie w sposób przemysłowy. Ten typ aguayo wypiera typ poprzedni ze względu na ogólną dostępność i niską cenę. Wykorzystywany jest w branży turystycznej. Nie posiada cech własnych określających przynależność do danej grupy lub społeczności.

Aby aguayo mogło pełnić rolę wyznacznika społecznej tożsamości, musi posiadać ściśle określoną kolorystykę i ornamentykę. Elementy te, czytelne dla rdzennych mieszkańców, wskazują na przynależność do

28 T. Gisbert, S. Arze, M. Cajías, Arte Textil y Mundo Andino, La Paz 2006, s. 68.

29 L. Castillo, El aguayo paceño, La Paz 2009, s. 37-39. 
określonej wspólnoty i pełnione w społeczności funkcje. Używany system znaków wymaga wtajemniczenia, aby mógł być zrozumiały. Luz Castillo precyzuje:

Boliwijskie aguaya wskazują na przynależność do grupy etnicznej, określonej wioski i regionu; w konsekwencji wzory i ornamentyka zmieniają się w zależności od regionu. Aguayo, za pomocą kolorów użytych w przestrzeni nazywanej pampą, określa tożsamość społeczną i rodzinną. Kobieta wychodząc za mąż, wnosi do swego aguayo zarówno elementy rodziny, z której się wywodzi, jak też przyjmuje elementy rodziny, do której wchodzi. W ten sposób aguayo staje się swoistym dokumentem tożsamości wskazującym na pochodzenie ${ }^{30}$.

Pampa jest przestrzenią dominującą w aguayo i jak opisuje Denise Y. Arnold: „ukazuje nam ziemię, na którą patrzymy; jest przestrzenią, którą obserwujemy z daleka. Jest to obszar, gdzie pasą się nasze zwierzęta; są to przestrzenie naszych łąk, kwiatów i wszelkiego drzewostanu" ${ }^{\text {I }}$. Za pomocą używanych w aguayo kolorów mieszkańcy przedstawiają naturalne środowisko, w którym żyją. „Kolory - zauważa Castillo - reprezentują geografię mieszkańców Płaskowyżu Andyjskiego, ich bliski związek $\mathrm{z}$ naturą, ich relacje z owocami ziemi, zwierzętami, kwiatami, z niebem i całą przestrzenią, w której żyją" ${ }^{2}$. I tak na przykład zieleń wyraża pastwiska i krzewy dojrzewających ziemniaków; kolor żółty odnosi się do obszaru, gdzie uprawia się szczawik bulwiasty, używany od wieków w tradycyjnej kuchni Indian peruwiańskich i boliwijskich, lub też do terenów, gdzie kwitnie na żółto krzew Calceolaria buchtieniana, którego kwiaty są używane w tradycyjnej medycynie; za pomocą koloru pomarańczowego oddaje się przestrzenie, gdzie rośnie roślina o nazwie misik'u, jej kwiaty używane są jako barwnik; fiolet przedstawia obszary, gdzie kwitną kwiaty q'ilaq'ila oraz gdzie uprawia się odmiany ziemniaków (np. axawiri, mujarilla) kwitnących w tym kolorze; biel symbolizuje kwiatostan ziemniaków odmian waych'a i luk' $i$; czerwień kwiatostan rośliny tanitani, kolor niebieski natomiast - niebo i rzeki33.

\footnotetext{
30 L. Castillo, El aguayo paceño, dz. cyt., s. 43.

31 D. Y. Arnold, Hilos Sueltos. Los andes desde el textil, La Paz 2007, s. 386.

32 L. Castillo, El aguayo paceño, dz. cyt., s. 44.

33 L. Castillo, El aguayo paceño, dz. cyt., s. 386-388.
} 
Pierwotne odniesienie do przyrody z biegiem czasu uległo zatarciu i do dziś kultywowane jest tylko przez nieliczne starsze osoby żyjące w środowisku wiejskim. Jest ono stosowane nadal w pierwszym rodzaju tkanin, posiadających wartość rytualną, używanych do sprawowania kultu. W aguayo drugiego typu używa się kolorów celem identyfikacji rodzinnej, bez odniesienia do wartości znaczeniowej, jaką dany kolor ma wyrażać. Rola kolorów sprowadza się więc do znaku identyfikującego: członkowie rodzin używają tych samych kolorów w zależności od stopnia pokrewieństwa lub powinowactwa. Natomiast w trzecim rodzaju aguayo, który jest już produktem przemysłowym, kolorystyka nie posiada wartości znaczeniowej i nie pełni funkcji identyfikatora przynależności rodzinnej.

Zróżnicowana i żywa kolorystyka aguayo związana jest z naturalną tęsknotą społeczności do wyrwania się z szarości andyjskiego krajobrazu. Dominującymi na tym obszarze barwami są kolor ziemi, spalonej słońcem trawy oraz kolor skał andyjskich szczytów. W miastach takich jak El Alto dominują kolory cegły i betonu. Stąd też żywa czerwień, intensywna zieleń, odcienie błękitów przerywają monotonię krajobrazu.

Obok kolorystyki, która, przynajmniej pierwotnie, wyrażała bliski kontakt mieszkańców regionu z otaczajacą ich przyrodą, także używane w aguayo wzory i figury posiadają określone znaczenie. Najczęściej używane są motywy roślinne, zoo- i antropomorficzne, jak również formy abstrakcyjne (np. zwierzęta mitologiczne), figury geometryczne itp.

Motywy używane w dekoracji tkanin można usystematyzować ze względu na okres historyczny, w którym dany motyw był dominujący. W okresie preinkaskim przedstawiano na tkaninach postaci bóstw oraz mitologicznych zwierząt (np. czteroskrzydłe ptaki). W okresie imperium Inków (sztuka cuscenia) przeważały formy geometryczne i antropomorficzne. W okresie Wicekrólestwa dominująca była ornamentyka florealna. W dekoracji tkanin wykorzystywano także wzory zaczerpnięte $\mathrm{z}$ herbów dynastycznych monarchii Europy (np. dwugłowy orzeł). Wraz z uzyskaniem przez kraje Ameryki Łacińskiej niepodległości i wejściem w okres republikański ikonografia tkanin zostaje wzbogacona o takie elementy, jak gałązki drzewa oliwnego, korony z liści laurowych oraz elementy zapożyczone z symboliki militarnej. Współcześnie można spotkać stylizacje środków transportu (samochody, samoloty, helikoptery). Elementy te wykorzystywane są na przemian z dekoracją tradycyjną - motywami zwierząt, roślin, fal morskich, motywami związanymi ze światem wierzeń, bóstw, wyobrażeń kapłanów składający ch ofiary. W tkaninach elementy mitologiczne, figury geometryczne i linie sinusoidalne przeplatają się z obrazami zaczerpniętymi ze 
świata realnego. Figury te nigdy jednak nie są przypadkowe, lecz stanowią sposób konceptualizacji świata: wyrażają obraz świata, jaki posiada i pragnie wyrazić osoba komponująca tkaninę za pomocą języka, który - aby był zrozumiały- wymaga swoistej inicjacji ${ }^{34}$.

Podobnie jak kolorystyka tkanin, także ikonografia jest elementem identyfikującym i wyróżniającym poszczególne rodziny. Każda rodzina posiada własny system znaków i kolorów, który wskazuje na stopnie wzajemnego pokrewieństwa i powinowactwa.

Ważną cechą andyjskich tkanin jest ich dualność. Każde aguayo zszyte jest z dwóch identycznie utkanych części. Wynika to z motywów praktycznych: tkaniny pierwszego i drugiego rodzaju wykonywane są ręcznie i dlatego ich maksymalna szerokość to ta, jaką można uzyskać, przekładając czółenko tkackie przez przesmyk na szerokość swobodnego ruchu ręki. Większy rozmiar tkaniny wymaga zszycia dwóch elementów. Fakt ten posiada jednak swoją wymowę w odniesieniu do zasady dualizmu, która jest jednym z podstawowych elementów kosmologii andyjskiej i organizacji społecznej Indian Aymara. Według kosmologii andyjskiej świat dzieli się na to, co jest w górze (hanan), i to, co jest na dole (hurin): dualizm mężczyzna | kobieta posiada swój odpowiednik na nieboskłonie: Słońce | Księżyc. Istnieje prawa (Ichoc) i lewa (Allauca) strona. System wierzeń nie dzieli jednak rzeczywistości na dobro i zło, na elementy pozytywne i negatywne. Elementy nie są sobie przeciwstawne i wzajemnie się wykluczające, lecz nawzajem się uzupełniają i dopiero razem tworzą jedność.

Komplementarność zakłada także określony podział obowiązków i stanowi o identyfikacji płciowej. Mężczyzna pracuje na roli i jako żołnierz uczestniczy w walkach: jego zadaniem jest zdobycie środków do przeżycia i zagwarantowanie bezpieczeństwa. Do obowiązków kobiety należy opieka i wychowanie dzieci oraz przygotowanie tkanin. Bardzo sztywne określenie ról społecznych i rodzinnych (gender) opiera się na zasadzie komplementarności i zapewnia możliwość przeżycia w trudnym klimacie i środowisku andyjskich szczytów. Kobieta i mężczyzna są dwoma rzeczywistościami wzajemnie uzupełniającymi się, których zjednoczenie czyni przeżycie możliwym ${ }^{35}$.

34 Istnieje obszerna bibliografia na temat ikonografii aguayo. Zob. T. Gisbert, S. Arze, M. Cajías, Arte Textil y Mundo Andino, dz. cyt., s. 9-15.

35 J. Estermann, Filosofía Andina. Sabiduría indigena para un mundo nuevo, La Paz 2006, S. I39-I40. 
Aguayo, odnosząc się do istniejącego w kosmologii dualizmu, składa się z dwóch części zwanych mankhalli. Kobiety w czasie przygotowywania tkaniny używają terminów ,jaqiptayaña” (przemienić w osobę) i „mayaptayaña” (przemienić w jedno), podkreślając przez to dualizm jedności. Tkanina wyraża w ten sposób komplementarność i jedność dwoistości: dwie części aguayo wskazują na równość kobiety i mężczyzny i jedność wynikającą z ich połączenia. Dotyczy to przede wszystkim tkanin przeznaczonych do ceremonii religijnych, jednakże obowiązuje też przy wykonaniu wszystkich tkanin z pierwszej i drugiej grupy ${ }^{36}$.

\section{Użycie aguayo}

Aktualnie używanie aguayo świadczy o przynależności do grupy metyskiej, określanej popularnie pejoratywnym słowem „cholo”. Tkanina ta używana jest przez „cholas” (kobiety metyskie) trudniące się głównie handlem lub też przygotowujące posiłki na targach. Aguayo jest nieodłącznym elementem krajobrazu miejskiego; stanowi połączenie kultury wiejskiej z miejską i identyfikowany jest $\mathrm{z}$ tradycyjnym obrazem kobiety w spódnicy z melonikiem na głowie (chola paceña). Wskazuje też na bliski związek matki z dzieckiem w kulturze, gdzie kobieta nigdy, nawet wykonując ciężkie prace fizyczne, nie rozstaje się ze swoim maleństwem. Aguayo określa również tożsamość i - jak już wspomniano powyżej - przynależność do konkretnej społeczności rodzinnej.

Tkanina ta odgrywa ważną rolę w procesie inicjącyjnym i wchodzenia w nowy etap życia. Jest podstawowym elementem zarówno codziennego życia, jak i działalności rytualnej i religijnej. Uncus, chuspas i llicllas są rodzajami aguayo przeznaczonymi wyłącznie do kultu i jako takie są czytelnym znakiem dla osób wtajemniczonych w system lokalnych wierzeń. Ich użycie niezgodne z przeznaczeniem (np. w liturgii katolickiej) traktowane jest jako świętokradztwo.

Poniżej przedstawiamy podstawowe formy zastosowania aguayo w życiu codziennym i podczas uroczystości o charakterze rodzinnym i wspólnotowym.

36 D. Y. Arnold, Hilos Sueltos...., dz. cyt., s. I68. 


\section{Użycie aguayo do przenoszenia ciężarów}

Drobna produkcja rolna, typowa dla obszaru wiejskiego Płaskowyżu Andyjskiego, wymaga transportowania produktów celem ich sprzedaży w miastach. Dlatego też kobiety tkały dla siebie aguayo, natomiast dla mężczyzn odpowiednik o nazwie mantiyu. Ten typ tkaniny w ostatnich latach został wyparty przez ogólnodostępne torby i plecaki. Kobiety jednak nadal preferują do noszenia produktów ręcznie tkane aguayo. Używane jest ono także w pracach rolnych do noszenia dziennych racji żywnościowych dla osób pracujących na roli. Kobiety przygotowują też w domach większe ilości potraw, które następnie sprzedają na miejskich targowiskach. Aguayo służy im do przenoszenia dużych naczyń wypełnionych jedzeniem.

Aguayo wykorzystywane jest więc do przenoszenia każdego rodzaju produktu o ciężarze, jaki dana osoba potrafi udźwignąć na plecach. Produkt umieszcza się w centrum rozłożonego płótna, mocuje się go dwoma przeciwległymi końcami tej chusty, a następnie za pomocą dwóch pozostałych rogów tkaniny ciężar zarzuca się na plecy i zawiązuje chustę na piersiach. W ten sposób powstaje swoisty rodzaj plecaka. Sposób ten nie tylko pozwala przenosić znaczny ciężar, ale ponadto nie krępuje rąk, a przez to umożliwia wykonywanie innych czynności. Po przybyciu na targowisko aguayo pełni funkcję płachty na której rozkładane są produkty.

Użycie aguayo konsoliduje się pod koniec XIX wieku, a ma to związek $\mathrm{z}$ procesem migracji kobiet aymara $\mathrm{z}$ obszarów wiejskich do miast. Wzmożony ruch migracyjny spowodowany był większym niż dotychczas zapotrzebowaniem mieszkańców miast na tanią siłę roboczą, jak również zwiększającym się popytem na produkty rolne. Od tego czasu notuje się liczniejsza obecność ludności indiańskiej w miastach takich, jak La Paz ${ }^{37}$.

W 1925 roku, z okazji stulecia ogłoszenia niepodległości Boliwii, prezydent Bautista Saavedra wydał dekret zabraniający wejścia na główny plac miasta La Paz (Plaza Murillo) mężczyznom pochodzenia indiańskiego, ubranych w tradycyjny strój. W związku z tym doszło do jeszcze wyraźniejszego podziału zadań: kobiety indiańskie i metyskie, którym prawo nie zabraniało wstępu do centrum administracyjnego, zaczęły trudnić się handlem, natomiast mężczyzni poświęcali się pracy na roli lub też znajdowali zatrudnienie w budownictwie czy drobnym przemyśle. Podział ról, gdzie kobiety poświę-

${ }_{37}$ S. Rivera Cusicanqui, Ser mujer indígena, chola o birlocha en la Bolivia postcolonial de los años 90, La Paz 1996, s. 48-56. 
cają się działalności handlowej i pracom służebnym w domach bogatych mieszczan, a mężczyzni innym formom zatrudnienia, sprawił ostatecznie, że aguayo zostało przypisane kobietom metyskim i indiańskim, gdyż praca mężczyzn nie wymagała przemieszczania się i dźwigania produktów.

Wyraźny podział zadań utrzymuje się do dnia dzisiejszego. To kobiety metyskie zajmują się działalnością handlową i małą gastronomią, a ponieważ wszystkie te czynności wymagają noszenia produktów, tym mocniej konsoliduje się użycie aguayo przez kobiety. Użycie aguayo przez mężczyzn ogranicza się do niektórych czynności i praktycznie tylko do obszaru wiejskiego. To chola poświęca się działalności handlowej, dzięki czemu osiąga sporą niezależność ekonomiczną, co sprawia, że kultura społeczności Płaskowyżu ma charakter zdecydowanie matriarchalny. Nadal też, pomimo że trasport zmotoryzowany dziś dominuje, aguayo jest nieodzownym elementem kobiecej aktywności i ${ }^{88}$.

\section{Użycie aguayo do noszenia dzieci}

Według opinii Teresy Gisbert użycie aguayo do noszenia dzieci nie jest dawną praktyką, gdyż jeszcze pod koniec XVIII wieku dzieci noszono w plecionym koszu w kształcie kołyski. Obecnie użycie aguayo do noszenia dzieci na plecach jest podstawową formą wykorzystania tej tkaniny. Dziewczyny będąc jeszcze nastolatkami uczą się tkać aguayo, które w przyszłości stanie się elementem określającym pełnię ich osobowej realizacji jako kobiety i matki. Troska o dziecko, wychowanie, karmienie i noszenie go to czynności, dzięki którym kobieta realizuje się nie tylko w wymiarze osobowym, ale także społecznym; do wypełniania tych funkcji przygotowuje się od najmłodszych lat. Także obecnie, gdy aguayo tkane przemysłowo jest ogólnie dostępne w handlu, to jednak to, który ma służyć do noszenia dziecka, nadal wykonywane jest ręcznie - nie tylko ze względu na większą wytrzymałość tkaniny tkanej w domowym warsztacie, ale także ze względu na znaczenie symboliczne, jakie tkaninie tej się nadaje ${ }^{39}$.

Aguayo używane do noszenia dzieci jest materiałem o dużych wymiarach, ma bowiem umożliwić swobodne owinięcie dziecka oraz przywiązanie go do ciała matki, tak aby nie krępowało jej ruchów, a jednocześnie uniemożliwiło wypadnięcie maleństwa. Wytwarzane jest ono z mocnej,

38 L. Castillo, El aguayo paceño, dz. cyt., s. 79-8I.

39 T. Gisbert, S. Arze, M. Cajías, Arte Textil y Mundo Andino, dz. cyt., I46. 
a zarazem delikatnej tkaniny, tak aby gwarantowało swobodę ruchów matki i nie powodowało otarć na skórze dziecka. Kolory używane przy wyrobie tego typu aguayo są żywe i radosne, co bez wątpienia ma pozytywny wpływ na dziecko.

Dzieci w okresie karmienia piersią (wawas) noszone są na plecach, co wynika nie tylko z praktyczności tego sposobu, gdyż ręce pozostają wolne, lecz również z koncepcji czasu, jaka istnieje w kosmologii andyjskiej. Według Aymara czas nie jest linearny, lecz cykliczny; ludzie poruszają się, widząc przed sobą własną przeszłość, którą już znają. Przyszłość natomiast znajduje się za plecami i nie można jej widzieć; jest ona jeszcze nieznana. Dlatego też dziecko, które należy do przyszłości, noszone jest na plecach ${ }^{40}$.

Zwyczajowo noworodka obwiązuje się w mniejszym aguayo jak mumię, z rękami unieruchomionymi przy ciele, aby nie odmroziło sobie dłoni i nie podrapało sobie twarzy paznokciami. Tak obwiązane umieszczone zostaje w większym aguayo. Dwa końce boczne chusty służą do przymocowania dziecka, natomiast dolna i górna końcówka chusty służą do umocowania go na piersiach matki. W ten sposób dziecko wraz z matką tworzą jedność.

Użycie aguayo w obrzęach przejścia: małżeństwa, porodu, postrzyżyn dziecka (obrzęd rutuchai), podczas uroczystości promocji i uzyskania stopni

Aguayo używane jest w ważnych momentach życia rodzinnego. Słowo jaqi (osoba, człowiek) w języku aymara stanowi rdzeń słowotwórczy zarówno dla słów określających małżonków, jak i tych, którymi opisuje się aguayo. Małżonków określa się słowami jaqichaña lub jaqiirpnaqaña, co oznacza dwie osoby, które poprzez wspólnotę małżeńską stają się jednością. Natomiast tkaninę, jaką jest aguayo, określa się też słowami jaqiptayaña lub mayaptayaña: są to dwie części materiału, które stają się jednością poprzez ich zszycie, nadające tkaninie znaczenie symboliczne.

W czasie obrzędów małżeństwa aguayo jest rozkładane na stole, przy którym zasiadają państwo młodzi. Tkanina jest oznaczona imionami nowożeńców, a w ornametyce przedstawione są życzenia dla młodej pary. Badacz kultury aymara Luz Castillo pisze: „kobieta, która przygotowuje się do zawarcia małżeństwa, tka dwa aguayo z imionami zarówno swoim, jak i swe-

40 K. A. Layme, El mistero del futuro, La Paz 2009, 2I. 
go przyszłego małżonka, co stanowi część posagu, jaki wnosi do rodziny"41. $\mathrm{Na}$ zakończenie uroczystości los padrinos odpowiedzialni za prezenty ${ }^{42}$ używają aguayo, aby zebrać do niego upominki i pieniądze dla małżonków.

W czasie porodu aguayo używane jest do masażu o znaczeniu rytualnym. Położne masują brzuch matki, aby dziecko ułożyło się właściwie przed przyjściem na świat.

Pierwsze postrzyżyny dziecka, rytuał o znaczeniu religijnym, zwany $r u$ tucha, jest obrzędem, w którym także wykorzystuje się aguayo. Na jednej $\mathrm{z}$ takich tkanin sadza się dziecko, na drugim aguayo natomiast umieszcza się przedmioty potrzebne do strzyżenia włosów (nożyce, dzban z wodą, naczynie, do którego zbierze się włosy). W jeszcze jednym aguayo znajomi i sąsiedzi składają upominki, np. produkty żywnościowe, liście koki. Na zakończenie obrzędu rutucha odbywa się rytualny posiłek, w czasie którego część upominków oraz obcięte włosy dziecka składane są w ofierze ku czci Pachamamy celem uproszenia zdrowego wzrostu dla dziecka. Umieszczenia dziecka na aguayu oznacza, że jest ono częścią andyjskiego świata i jego miejsce jest pośród pampy i pól uprawnych.

W czasie uroczystości z okazji zakończenia nauki w szkole, zdobycia tytułu zawodowego lub zakończenia służby wojskowej zastosowanie aguayo jest szerokie. Materiałem tym ozdabia się centralny stół, przy którym zasiadają honorowi goście (np. przedstawiciele miejscowych władz). Przy pomocy aguayo ozdabia się salę, gdzie odbywa się uroczysty posiłek. Na aguayo umieszcza się liście koki, pełniące funkcję rytualną. Na nim także umieszcza się produkty na tradycyjne apthapi - wspólnotowy posiłek o charakterze rytualnym, który składa się z produktów, przyniesionych przez wszystkich uczestniczących $\mathrm{w}$ uroczystości. W aguayo wnoszona jest osoba, która świętuje zdobycie tytułu lub stopnia w społecznej hierarchii. Rodzina ofiarowuje osobie świętującej specjalne aguayo, mogła zebrać do niego prezenty, które otrzymała z tej okazji, a później z szacunkiem przechowywać w nim dyplom lub inny dokument potwierdzający zdobyte

41 L. Castillo, El aguayo paceño, dz. cyt., s. 87.

42 Funkcja padrinos jest bardzo rozpowszechniona nie tylko w kulturze andyjskiej, ale także w większości krajów Ameryki Łacińskiej. Pełnią oni rolę sponsorów zabezpieczających to, co jest konieczne do właściwego przebiegu uroczystości. Wybiera się zatem padrinos „od obrączek”, których zadaniem jest zakup i ofiarowanie ich małżonkom. Zadaniem padrinos „od orkiestry" jest sfinansowanie zespołu muzycznego itd. W tym wypadku zadaniem padrinos „od prezentów” jest zebranie upominków od wszystkich uczestników oraz osobisty wkład, tak aby prezent posiadał wymierną wartość. 
kwalifikacje. Aguayo wykorzystywane jest także jako część stroju kobiet uczestniczących w ceremonii.

Aguayo, wyznaczając kolejne etapy życia ludzkiego, staje sie ważnym elementem rodzinnego patrymonium. Matka przygotowuje aguayo z imieniem dziecka, aby przekazać mu w ten sposób pamięć o sobie. Po śmierci rodzina zmarłej osoby dzieli pomiędzy siebie używane w domu tkaniny. W ten sposób aguayo pełni rolę relikwii, która jest dziedziczona z pokolenia na pokolenie.

Użycie aguayo we wspólnocie lokalnej: podczas apthapi, zgromadzeń lokalnych władz oraz ceremonii przekazania insygniów władzy

Apthapi, czyli wspólnotowy posiłek, odgrywa bardzo ważną rolę w życiu społecznym indiańkich wiosek. Słada się on z produktów (np. ziemniaków, kukurydzy, mięsa, ryb, nabiału) przyniesionych przez wszystkich członków danej społeczności. Produkty te gromadzone są na rozłożonym aguayo. $\mathrm{W}$ ten oto sposób wyraża on geografię andyjską, gdzie na upranych polach otrzymuje się dary, którymi ludzi obdarza Pachamama. Aguayo wyraża także wspólnotę łączącą wszyskich członków społeczności, którzy tylko tworząc jedność mogą cieszyć się przychylnością Matki Ziemi.

Aguayo wykorzystywane jest również do przystrojenia bram i łuków budowanych na drodze do wioski, gdy witani są ważni goście lub przedstawiciele władzy. Dwie belki wertykalne pokrywa się w całości tymi tkaninami, natomiast aguayo, swobodnie zwisające na belce horyzontalniej, dekorowane jest kwiatami, owocami lub symbolami narodowymi. W czasie uroczystych pochodów wykorzystuje się aguayo do dekoracji wozów alegorycznych, poruszający ch się na czele poszczególnych grup tancerzy.

Aguayo pełni także funkcję obrusu, który umieszcza się na stole, przy którym zbierają się na posiedzeniach lokalne władze i to na nim podpisywane są ważne dla społeczności dokumenty. W czasie posiedzeń władz to na nim znajdują się liście koki, które w społeczności posiadają wymiar sakralny (hoja sagrada) i spożywane są w dużych ilościach. Liście koki odgrywają ważną rolę w tradycyjnej kulturze andyjskiej. W regionach górskich są konieczną do przeżycia substancją, gdyż ich żucie zwalcza objawy choroby wysokościowej.

W uroczystościach związanych ze zmianą władz, schodzący z urzędzu przekazują nowo wybranym władzom owinięte w aguayo symbole piastowanych funkcji (pieczęć, księgę protokołów, itd.). 
I52 || Kasper Mariusz Kaproń OFMCap

Użycie aguayo w tańcach folklorystycznych

oraz w czasie uroczystych manifestacji

W tańcu folklorystycznym moseñada muzycy i tancerze używają aguayo jako elementu symbolicznego i dekoracyjnego. Kolorystyka i ornamentyka aguayo zależy od wieku tancerzy: młodzi używają tkanin w kolorach jasnych i żywych, podkreślając w ten sposób młodość i radość, natomiast osoby starsze zwracają większą uwagę na jakość wykonania i ikonografię, przez co pragną wyrazić zdobytą mądrość i posiadane doświadczenie. W uroczystościach o charakterze folklorystycznym grupy używają tkanin wykonywanych specjalnie na każde święto.

$\mathrm{W}$ tańcu moseñada pary niezwiązane węzłem małżeńskim trzymają aguayo $\mathrm{w}$ jednej ręce (mężczyzna $\mathrm{w}$ lewej, kobieta $\mathrm{w}$ prawej), natomiast małżonkowie trzymają go w obu dłoniach. Osoby stanu wolnego tańczą z pustym aguayo, natomiast aguayo par małżeńskich wypełnione jest różnymi produktami rolnymi jako znak płodności i posiadanego bogactwa.

Aguayo wykorzystywane jest także w uroczystych pochodach organizowanych z racji świąt państwowych (np. 6 sierpnia z okazji święta niepodległości Boliwii). Jest używane jako dekoracja wozów alegorycznych poruszających się na czele grup uczestniczących w pochodzie oraz jako dekoracja trybuny honorowej, na której zasiadają przedstawiciele władz oraz zaproszeni goście. Aguayo stanowi tło trybuny, są i do niego przymocowane symbole narodowe oraz wizerunki bohaterów ojczyzny.

\section{Użycie aguayo $w$ uprawie roli $i$ hodowli zwierzat}

Rolnictwo jest podstawowym działem gospodarki mieszkańców Płaskowyżu Andyjskiego. W czasie zasiewów aguayo wykorzystywane jest jako płachtę, z której sieje się zboże. Do niego wkłada się ziemniaki przeznaczone do posadzenia w ziemi. W nim nosi się posiłek dla osób pracujących na roli.

Przy znaczeniu zwierząt, w rycie zwanym k'illpha, wykorzystuje się aguayo $\mathrm{w}$ kolorystyce czerwieni i zieleni. Czerwień odnosi się do krwi znaczonych zwierząt i oznacza płodność oraz jedność z Pachamama. Zieleń odnosi się do życia i barwy pól w lutym, miesiącu, w którym znaczy się zwierzęta. Obrzęd ten posiada wymiar religijny. W aguayo trzyma się przedmioty potrzebne do znaczenia zwierząt (nóż, igła, pojemnik z alkoholem) oraz rzeczy, które zostaną złożone w ofierze ku czci Pachamamy. 
Aguayo jako tkanina przemysłowa

W ostatnich latach rozpowszechniła się przemysłowa produkcja aguayo o różnorodnej kolorystyce i ikonografii z regionu Cuzco i Tiahuanaco. Aktualnie cena metra tkaniny wynosi ok. 5 USD, co czyni ją ogólnie dostępną. Tkaninę produkowaną w sposób przemysłowy wykorzystuje się na szeroką skalę w turystyce. Ogólnie dostępne są spodnie, bluzy, kamizelki, torby, plecaki, obrusy, artykuły gospodarstwa domowego, piórniki i inne produkty przygotowywane z użyciem tego materiału. Evo Morales Ayma, aktualny prezydent Boliwii, używa ubrań ozdobionych elementami tradycyjnego andyjskiego aguayo. Świadczy to jednak o postępujących zmianach w zastosowaniu aguayo i odejściu od jego pierwotnej wymowy i symboliki.

\section{WYKORZYSTANIE AGUAYO W LITURGI KATOLICKIEJ}

Jak wskazano powyżej, aguayo posiada bardzo szerokie zastosowanie w życiu rodzinnym, społecznym i politycznym mieszkańców Płaskowyżu Andyjskiego. Nie tylko pełni funkcję użytkową, ale posiada także wymiar symboliczny: ukazuje dualistyczną koncepcję świata typową dla kosmologii andyjskiej. Kolorystyka i ikonografia tkaniny są elementami identyfikującymi, określającymi przynależność rodzinną i pełnioną funkcję społeczną. Użycie tej tkaniny jest ściśle związane z obrzędowością Indian Płaskowyżu, stąd rodzi się słuszne pytanie o możliwości zastosowania aguayo w liturgii katolickiej. Brak publikacji dotyczących tego zagadnienia sprawia, że w opracowaniu bazować będziemy jedynie na danych uzyskanych od osób zwiazanych z tematyką, zarówno etnologów i badaczy kultury, jak i duszpasterzy i teologów.

Silvia Arze ${ }^{43}$, historyk, współautorka monografii Arte textil y mundo andino $^{44}$, jednego $\mathrm{z}$ najobszerniejszych opracowań dotyczących tkanin andyjskich, jest przekonana, że początki użycia aguayo jako tkaniny służącej do wyrobu szat liturgicznych (stuł i ornatów) należy datować na koniec lat 6o-ych XX wieku; praktyka ta wiąże się z rodzącym się wówczas w teolo-

43 Wywiad z dr Silvią Arze przeprowadzony w grudniu 20I5; T. Gisbert, S. Arze, M. Cajías, Arte textil ..., dz. cyt., La Paz 2006.

44 T. Gisbert, S. Arze, M. Cajías, Arte textil y mundo andino, Pa Paz I987. 
gii kierunkiem, jakim jest teologia wyzwolenia. Pragnienie zbliżenia się do najuboższych oraz identyfikacji z warstwami społecznie dyskryminowanymi (Indianami oraz mieszkańcami wsi) zrodziło ideę wykorzystania niektórych elementów typowych dla tych grup i wprowadzenia ich do liturgii. Najprawdopodobniej to właśnie z tego powodu zaczęto używać aguayo do wyrobu stuł, ornatów i obrusów na ołtarz. Szaty i inne tkaniny liturgiczne szyte z aguayo były używane głównie w parafiach wiejskich i miastach, gdzie przebywała duża ilość ludności napływowej ze wsi. Użycie tych tkanin w liturgii było mocno promowane przez kapłanów i intelektualistów zaangażowanych $\mathrm{w}$ proces wprowadzania reform II Soboru Watykańskiego i wspierających ruchy rewolucyjne w burzliwym okresie napięć społecznych oraz przewrotów wojskowych.

Okres reformy soborowej oraz początki teologii wyzwolenia w Boliwii przypadają na lata bezpośrednio po rewolucji narodowej w 1952 roku, kiedy to zniesiono obowiązujący do tego czasu system niewolniczy, wprowadzono reformę rolną oraz przyznano wszystkim obywatelom prawa wyborcze. W konsekwencji wprowadzenia reform ludność indiańska zaczęła częściej pojawiać się w miastach i aktywniej uczestniczyć w życiu społecznym, jak również brać bardziej czynny udział w uroczystościach o charakterze zarówno religijnym, jak i folklorystycznym. Typowe dla ludności indiańskiej strój oraz rodzaj materiału, jakim jest aguayo, stały się widoczne i popularne w miastach nie tylko Płaskowyżu, lecz również w innych częściach kraju. Strój ten, ogólnie rozpoznawalny i utożsamiany z kulturą indiańską, stał się synonimem całej kultury andyjskiej i atrakcyjną pamiątką dla przybywających na ten teren turystów. Wobec rosnących potrzeb branży turystycznej rozpoczyna się w tym okresie przemysłowa produkcja tej tkaniny. Ogólnie dostępne i tanie aguayo tkane w sposób przemysłowy pozwoliło na produkcję szerokiego asortymentu produktów bez koniecznosci przycinania, a tym samym niszczenia ręcznie wykonanych tkanin.

Warto także wspomnieć - stwierdza Silvia Arze - że w kulturze andyjskiej tkaniny stanowiły nieodłączny element ceremonii i obrzędów tradycyjnego systemu wierzeń religijnych. W okresie bezpośrednio po konkwiście miejscowi tkacze przygotowywali na potrzeby świątyń katolickich tkaniny, które pełniły funkcję dywanów lub różnego rodzaju nakryć i dekoracji. Wykonywane one były przez miejscowych rzemieślników, jednak z reguły miały europejską ornamentykę, niekiedy wzbogaconą scenami biblijnymi. Tylko sporadycznie tkano przeznaczone do kościołów tkaninyz typowo indiańską ikonografią. Przykładem może być unku, obecnie w zbiorach Muzeum Narodowego Etnografii i Folkloru (MUSEF) w La Paz. 
Jest to tkanina nieznanego pochodzenia, popularnie nazywana unku santo. Była używana jako element dekoracyjny, z całą pewnością nie posiadała charakteru ściśle liturgicznego. W miejscowości Totora, niedaleko Cochabamby, do końca XX wieku istniało prężne centrum tkackie, produkujące tkaniny, w tym dywany, przeznaczone do kościołów. Nie wiemy jednak, czy wykonywano tam inne tkaniny dekoracyjne, w tym przeznaczone do bezpośredniego użytku w liturgii.

Silvia Arze uczestniczyła jako ekspert w pracach katalogowania zbiorów Muzeum Bazyliki św. Franciszka w La Paz i sporządziła opis ornatów i innych szat pochodzących z XVIII-XX wieku. Żaden z ornatów nie posiadał elementów zaczerpniętych $\mathrm{z}$ tkanin indiańskich $\mathrm{i}$ ani jeden nie był wykonany z aguayo. Jest to ważne o tyle, że kościół św. Franciszka w La Paz był najstarszym kościołem w mieście przeznaczonym dla ludności indiańskiej $i$ jedną z trzech parafii znajdujących się w dzielnicach zamieszkałych przez Indian. Świadczy to o tym, że aguayo i inne tkaniny indiańskie nie były wykorzystywane do przygotowania szat liturgicznych.

José Luis Lima Mamani ${ }^{45}$, wykładowca języka aymara na Wydziale Językoznawstwa Uniwersytetu w El Alto, na podstawie prezentowanego wyżej, opracowanego przez Luz Castillo podziału tkanin na ch'ankha awayu, lana awayu i ilu awayu wskazuje, że pierwszy typ posiada charakter obrzędowy i używany jest głównie przez rdzennych mieszkanców Płaskowyżu. Ze względu na swą charakterystykę regionalną i ściśle określone zastosowanie użycie go do celów innych od zamierzonych, w tym w kulcie katolickim, traktowane jest jako akt profanacji i jest ofensywne w stosunku do Indian. Nie można używać tkanin należących do tej grupy materiałów, opierając się jedynie na ich walorach estetycznych. Tkaniny te posiadają określone znaczenie, wyrażone w ich ornamentyce i kolorystyce, czytelne dla ludności indiańskiej, i dlatego też ich użycie w liturgii katolickiej uznawane jest wręcz za kradzież i znieważenie miejscowej społeczności. Także aguayo drugiego typu, używane głównie przez kobiety metyskie, posiada swoją wartość znaczeniową określającą tożsamość rodową, a jego zastosowanie ogranicza się zasadniczo do transportu dzieci i produktów. Użycie tego rodzaju tkaniny do innych celów jest niezrozumiałe. Do wyrobu stuł i ornatów stosuje się trzeci typ aguayo, który wykorzystywany jest głównie w branży turystycznej. Tkaniny tego typu, z ikonografią inkaską i zaczerpiętą z regionu Tiahuanaco, produkowane są w różnorodnej kolorystyce i posiadają jedynie

45 Wywiad przeprowadzono w marcu 2016. 
wartość estetyczną. Użycie tego rodzaju aguayo nie spotyka się z krytyką mieszkańców, jednakże brak wartości znaczeniowej tych tkanin czyni to użycie pozbawionym treści. Jest formą synkretyzmu kulturowego, pragnącego nawiązać do wartości lokalnej kultury, ostatecznie jednak znaczenie, jakie pragnie się nadać tkaninie, jest niezrozumiałe zarówno dla rdzennych mieszkańców regionu, jak i dla ludności metyskiej. Ponadto ludność kreolska, czyli potomkowie białych osadników, zamieszkująca głównie w miastach i mająca poczucie bycia klasą wyższą, zdecydowanie odrzuca ten typ tkanin, utożsamiając go z Indianami oraz mieszkańcami wsi.

Antropolog Eva Fischer ${ }^{4} \mathrm{z}$ Institute of Social Anthropology Uniwersytetu w Bernie w Szwajcarii, specjalizująca się w tkaninach wyrabianych przez Indian Aymara i Quechua, zwraca uwagę na zmiany, jakie dokonały się w ciągu ostatnich I5 lat w strukturach społecznych regionu. Użycie aguayo produkowanego przemysłowo znajduje coraz szersze zastosowanie, zatraca się w związku z tym wymiar symboliczny tkaniny. Na podstawie własnego doświadczenia i badań przeprowadzonych wśród mieszkańców Płaskowyżu wskazuje na pewne zastosowanie tradycyjnych tkanin w liturgii katolickiej. Zna przypadki, kiedy w niektórych wioskach księża używali specjalnie przygotowanego poncha, które pełniły funkcję ornatu. Również w procesji $\mathrm{z}$ darami wykorzystywano tradycyjną tkaninę incuña o wyrazistym znaczeniu rytualnym; owijano w nią dary składane na ołtarzu. Także dla figur świętych w ołtarzach wykonywano szaty z tradycyjnych tkanin andyjskich.

Juan Carlos Espinoza Coca ${ }^{47}$, doktorant na Wydziale Teologicznym Katolickiego Uniwersytetu św. Pawła w Cochabamba, silnie podkreślający swą przynależnośc do grupy Indian Quechua, zdecydowanie odrzuca możliwość użycia tradycyjnych tkanin w liturgii Kościoła. Tkaniny te posiadają bowiem określoną wartość znaczeniową i są środkiem służącym do wyrażenia przynależności do określonej grupy społecznej. W ornamentyce, jaka stosowana jest w aguayo, nawiązuje się często do kosmologii andyjskiej i przedstawia bóstwa opiekuńcze należące do panteonu bóstw mniejszych (np. wąż, żaba, mrówka, ogień, kwiaty, motyle). Ornamentyka może także odnosić się do bóstw większych kosmologii andyjskiej: Słońce (Inti), Księżyc (Kylla), Ziemia (Pachamama). Tkaniny, jak np. inkuña, chuspa lub llok'e, wykonywane zawsze $\mathrm{z}$ wełny szlachetnych zwierząt (np. wikunia), posiadają silne znaczenie sakralne i są wykorzystywane w obrzędach religii tradycyjnych.

${ }^{46}$ Wywiad przeprowadzono w marcu 2016.

47 Wywiad przeprowadzono w kwietniu 2016. 
Niektóre z tych tkanin używane są wyłącznie przez yatiris (kapłanów religii tradycyjnych) i pełnią funkcję, którą można porównać do funkcji paliusza arcybiskupów Kościoła katolickiego. Wykorzystywanie tych elementów w liturgii katolickiej należy określić jako pseudoinkulturację; świadczy o całkowitym niezrozumieniu natury i wymowy tych tkanin i odbierane jest przez ludność miejscową jako ofensywne. Bardziej niż inkulturacja jest to synkretyzm religijny, świadczącyy o pomieszaniu znaczeń i niezrozumieniu wartości semantycznej znaku, jakim jest aguayo. Dlatego też duchowni wywodzący się z ludności indiańskiej zdecydowanie optują za tradycyjnymi szatami liturgii rzymskiej, bez jakichkolwiek nawiązań do tkanin takich jak aguayo.

Również Ariel Claros López ${ }^{48}$, student teologii przygotowujący się do święceń kapłańskich, reprezentujący społeczność metyską, zdecydowanie sprzeciwia się liturgicznemu użyciu aguayo. W tkaninie tej kolory i figury posiadają swoje znaczenie. Za pomocą bogatej ornamentyki chce się ukazać chaotyczną wizję świata. O wyborze koloru tkaniny decyduje czas jej zastosowania: odcienie zieleni używane są w okresie zasiewów, a brązy w czasie zbiorów. Do noszenia dziecka używa się aguayo w różnych odcieniach koloru niebieskiego, natomiast do transportowania produktów używa się tkanin, w których przeważający jest kolor zielony. Jest to tkanina posiadająca określone zastosowanie i jej użycie w liturgii jest całkowicie niezrozumiałe dla miejscowej ludności. To, że w miejscowych sklepach i na bazarach można nabyć stuły wykonane z aguayo, należy tłumaczyć popytem na te produkty wśród zagranicznych turystów. Silnie rozwijający się przemysł turystyczny i zapotrzebowanie na pamiątki sprawia, że z aguayo wykonuje się różne przedmioty, w tym także kapłańskie stuły.

David Alcala Quispe ${ }^{49}$, kapłan zakonny wywodzący się z ludności Aymara, urodzony w niewielkiej wiosce Tocopa usytuowanej nad brzegiem jeziora Titicaca, także dystansuje się od użycia aguayo w liturgii. Mieszkańcy zwyczajnie nie rozumieją znaczenia, jakie ksiądz pragnie nadać tradycyjnym tkaninom posiadający $\mathrm{m}$ swoją określoną wymowę i symbolikę.

Victor Codina ${ }^{50}$, hiszpański teolog i emerytowany profesor Katolickiego Uniwersytetu w Boliwii, uważa, że używane w Andach aguayo zbyt mocno utożsamiane jest z kobietą noszącą na swych plecach dziecko i dlatego

\footnotetext{
48 Wywiad przeprowadzono w kwietniu 2016.

49 Wywiad przeprowadzono w kwietniu 2016.

50 Wywiad przeprowadzono w kwietniu 2016.
} 
zastosowanie tej tkaniny przez celebransa $\mathrm{w}$ liturgii jest nieodpowiednie. Przyznaje jednak, że w krajach Ameryki Środkowej użycie w liturgii tamtejszych tkanin tradycyjnych jest powszechnie i pozytywnie akceptowane.

Potwierdza to biskup meksykańskiej diecezji San Cristóbal de Las Casas, Felipe Arizmendi Esquivel, uczestniczący aktywnie w pracach na rzecz inkulturacji liturgii rzymskiej na obszarach zamieszkałych przez rdzennych mieszkańców Centralnej Ameryki:

Indianie bardzo sobie cenią to, że w liturgii używamy tkanin wywodzących się z ich kultury. Sami ofiarowali mi kilka mitr, w których dekoracji zastosowano wzornictwo najliczniejszych grup etnicznych zamieszkujących terytorium mojej diecezji: Indian Tsotsiles i Tseltales. W katedrze posiadamy około 50 ornatów w kolorystyce i ornamentyce typowej dla tutejszych grup etnicznych. Używamy tych szat w czasie uroczystych celebracji i spotyka się to z powszechną akceptacją zarówno Indian, jak i pozostałych wiernych. Używamy ich nie ze względów folklorystycznych, lecz jako wyraz wcielenia Kościoła w tutejszą kulturę.

Osobiście bardzo wysoko sobie cenię wszelkiego rodzaju wysiłki mające na celu wykorzystanie w liturgii nie tylko piękna i harmonii kolorów indiańskich tkanin, ale także ich bogatej symboliki, pod warunkiem jednak nadania im wymiaru chrystologicznego i eklezjalnego, który musi być uwzględniony. $\mathrm{W}$ ten sposób elementy rdzennych kultur zaadaptowane w liturgii będą wyrażać nie tylko „ziarna”, lecz również „dojrzałe owoce ewangelizacji”. Wiara bowiem nie niszczy historii i kultury, nie odrzuca jej, lecz ją przyjmuje, aby przemieniać ją w Chrystusie.

To w ten właśnie sposób powinniśmy postępować, zbliżając się z należnym szacunkiem do mitów i tradycji tutejszych plemion: nie zatrzymując się na tych elementach, jakbyśmy byli antropologami i badaczami kultury, zafascynowani rdzennymi tradycjami, lecz - bazując na miejscowych tradycjach naszym obowiązkiem jest głosić w sposób wyraźny i zdecydowany Chrystusa. Bez tego tutejsze społeczności nie osiągną pełni, jakiej Bóg pragnie dla nich ${ }^{51}$.

Biskup Felipe Arizmendi Esquivel jest jednym z najbardziej zaangażowanych w działania na rzecz inkulturacji liturgicznej hierarchów w Konferencji Episkopatów Ameryki Łacińskiej (CELAM). Wprowadzając do liturgii elementy zapożyczone z kultury lokalnych społeczności, bardzo

\footnotetext{
51 Korespondencja z dnia I6 kwietnia 2016.
} 
skrupulatnie przestrzega procedur zalecanych w dokumentach Stolicy Apostolskiej. Poprzez aktywność na forum CELAM i publikacje uwrażliwia innych biskupów i osoby zaangażowane, aby z odwagą podejmowali wysiłki na rzecz inkulturacji w liturgii, podkreślając równocześnie konieczność roztropności i obowiązek wierności zasadom zawartym w dokumentach Magisterium $^{52}$. Należy więc przyjąć, że wprowadzenie do liturgii tkanin Indian Ameryki Środkowej nie było improwizowane i zostało poprzedzone wcześniejszym studium. Czy to samo można powiedzieć o użyciu andyjskiego aguayo do wykonania szat liturgicznych? Wypowiedzi zarówno badaczy kultury i historyków sztuki, jak i rdzennych mieszkańców Płaskowyżu wykluczają jednoznacznie stosowność takiego rozwiązania. Użycie aguayo w liturgii przez rdzennych mieszkańców odczytywane jest jako akt profanacji, wśród ludności metyskiej rodzi niezrozumienie, wśród ludności kreolskiej spotyka się z pogardą, a jedynie przez zagranicznych turystów przyjmowane jest z życzliwością. To ostatnie jest jednak spojrzeniem osób, które zatrzymują się jedynie na wymiarze folklorystycznym tkaniny, bez wejścia w głębię jej symboliki.

Po odrzuceniu możliwości użycia aguayo do wyrobu szat liturgicznych być może trzeba byłoby podjąć refleksję na temat innych form zaadaptowania tej tkaniny w liturgii. W obrzędowości ludów tradycyjnych tkanina ta służy do składania na niej darów ofiarnych. Wykorzystywana jest do przechowywania liści koki, które uznawane są przez lokalnych mieszkańców za roślinę świętą, gdyż pozwala przeżyć w niesprzyjającym, wysokogórskim klimacie: niweluje uczucie głodu i zmęczenia oraz rozrzedza krew, co jest niezbędne do życia na wysokości ponad 4.000 m n.p.m. Podczas apthapi, spożywa się produkty, które składa się na rozłożonym aguayo: jest to posiłek wspólnotowy, którym uczestniczą wszyscy mieszkańcy wioski w nim; przynoszą dary, które zostaną później spożyte. Wreszcie aguayo jest znakiem nowego życia, gdyż to w nim matka nosi swoje dziecko.

Nowe życie, pokarm pozwalający przezwyciężyć największe trudności, wspólnotowy posiłek, który wymaga zaangażowania się wszystkich członków poprzez złożenie daru, a jednocześnie pozwala posilić się do sytości wszystkie te elementy ukierunkowują na rzeczywistość Eucharystii. Być może właściwsze niż wyrób ornatów byłoby użycie aguayo jako korporału, ołtarzowego obrusa lub tkaniny, w której wierni przynoszą dary ofiarne.

52 Zob. F. Arizmendi Esquivel, Logros y retos de la inculturación litúrgica en los pueblos indígenas, „Boletín CELAM” 317-318 (2007), s. 65-76. 


\section{ZAKOŃCZENIE}

W procesie inkulturacji sztuka musi harmonizować z obiektywnymi kryteriami, wskazanymi przez Kościoł, aby będąc wyrazem piękna, mogła służyć ostatecznemu celowi, jakim jest oddanie czci Bogu. Wszystkie gałęzie sztuki sakralnej mają nie tylko wyrażać piękno tworzone przez artystę, ale także sprzyjać oddawaniu czci i kontemplacji Tego, który jest Stworzycielem wszystkiego, co piękne, i Jego Syna, w którego człowieczeństwie odkrywamy prawdziwe piękno.

Warto zacytować trafną obserwację byłego mistrza ceremonii papieskich, abpa Piera Mariniego:

W oparciu o doświadczenie zdobyte w czasie podróży apostolskich Ojca Świętego przekonałem się, że czasami w sferze muzyki, architektury sakralnej i innych dziedzin sztuki tworzone są dzieła, które nie sprzyjają osiagnięciu celu, jaki nakreśliła reforma liturgiczna. Odnowa w tych obszarach - podkreślają to eksperci - może przynieść zamierzone owoce, jeżeli zadanie weryfikacji powierza się komisjom, najlepiej interdyscyplinarnym, złożonym z ekspertów, którzy są zdolni zintegrować wymogi współczesnej wrażliwości z właściwym zrozumieniem obrzędów i posług liturgicznych ${ }^{53}$.

W dalszej części, odnosząc się bezpośrednio do celebracji papieskich, abp Marini pisze:

Niektóre celebracje wyróżniała duża ilość elementów zaadaptowanych. Przy okazji inauguracji i zamknięcia synodów afrykańskiego, azjatyckiego i poświęconego Oceanii, celebracje Mszy świętej zostały ubogacone poprzez wprowadzenie do liturgii elementów zaczerpniętych z kultury tamtejszych ludów. Sam papież podkreślał konieczność inkorporacji elementów kulturowych w tych celebracjach: „Jestem też głęboko wdzięczny - powiedział Jan Paweł II - zespołowi roboczemu, który tak starannie przygotował liturgie eucharystyczne, sprawowane na otwarcie i zamknięcie Synodu. Zespół, w którego skład wchodzili teologowie, liturgiści oraz znawcy afrykańskich śpiewów

53 P. Marini, Liturgia y Belleza. Nobilis pulchritudo, Bilbao 2006, 47. 
i liturgicznych środków wyrazu, nadał tym liturgiom, zgodnie z moim pragnieniem, wyraźny charakter afrykański”'54.

Wyzwanie duszpasterskie, jakim jest ,inkulturyzowana” liturgia, szczególnie liturgia Eucharystii, pozostaje zadaniem pilnym i bardzo ważnym dla Kościoła nie tylko latynoamerykańskiego. W zależności od tego, jak zostanie ona zrealizowana, w dużej mierze zależeć będzie skuteczność działalności ewangelizacyjnej i żywe uczestnictwo wiernych w świętych obrzędach. Liturgia autentycznie ,inkulturyzowana” nie może jednak być realizowana pospiesznie. Każda zmiana musi być poprzedzona uprzednim dogłębnym studium i wymaga wielkiej cierpliwości. W liturgii nie dokonuje się zmian w oparciu o kaprys pewnych grup lub też na podstawie powierzchownych ekspertyz i szybkich decyzji, lecz wprowadza się je stopniowo i musi je poprzedzać dogłębne studium, co wymaga też stosownego czasu. Prawidłowa inkulturacja to rezultat zdrowego napięcia istniejącego pomiędzy liturgią a kulturą, konkretną akcją sakramentalną a instytucjami kulturowymi Kościoła lokalnego ${ }^{55}$.

W latach poprzedzających Sobór i w okresie reformy posoborowej studia liturgiczne rozwinęły się znakomicie: posiadamy wydania krytyczne źródeł liturgicznych, wspaniale rozwinęły się studia w zakresie historii liturgii, wkład innych dyscyplin naukowach i działów nauk, takich jak semantyka i semiotyka, otworzyły nowe perspektywy dla rozwoju liturgiki. Oceniając pozytywnie dotychczasowe efekty prac inderdyscyplinarnych z zakresu badań nad kulturą i liturgią, należy intensyfikować działania celem znalezienia odpowiedzi na następujące kwestie: Jakie wartości zakorzenione w kulturze mogą być zasymilowane przez liturgię chrześcijańską? Jak rozwiązać problem różnorodności kultur w ramach tej samej wspólnoty eklezjalnej? Jakie elementy kulturowe określają tożsamość danego ludu, a jakie są związane z partykularnymi grupami?

Nie można zamykać się przed żadną możliwością, każdą z nich należy z powagą i dokładnie przeanalizować. Zmiany motywowane snobizmem lub wprowadzone przez liturgicznych i pastoralnych amatorów, zamiast pomagać w czynnym uczestnictwie w liturgii, jedynie szkodzą i dezorientują

${ }_{54}$ P. Marini, Liturgia ..., dz. cyt., s. 89. Słowa Jana Pawła II cytowane przez Mariniego znajdują się w: Jan Paweł II, Adh. apost. Ecclesia in Africa (I4.09. 1995), 25.

55 Zob. J. Aldazábal, Lecciones de la historia sobre la inculturación, „Phase” 206 (I995), s. $107-108$. 
wiernych. W działaniach na rzecz inkulturacji konieczna jest wielka roztropność. Jan Paweł II w liście Vicesimus quintus annus wyraźnie zwrócił uwagę na to, że: „różnorodność liturgiczna może być źródłem ubogacenia, w innych zaś przypadkach przyczyną napięć, nieporozumień, a nawet schizm" (VQA I6).

IV Instrukcja zwraca uwagę na „konieczną roztropność” odnośnie do tego wszystkiego, co dotyczy inkulturacji ${ }^{5}$. Szczególnie zwraca uwagę na fakt, że „na tym polu (inkulturacji obrządku rzymskiego) potrzeba wychowania i czasu, by uniknąć zjawisk odrzucenia lub przywiązania się do form wcześniejszych" (VL 46).

Nie należy się dziwić, że działania w zakresie inkulturacji mogą rodzić uczucia lęku i daleko posuniętą ostrożność, gdyż dotykamy istotnych treści wiary chrześcijańskiej, które bardzo często stały się także wartościami kulturowymi określającymi tożsamość chrześcijanina. $Z$ tego też powodu należy traktować te zagadnienia z należną powagą, a ewentualne zmiany wprowadzać z pedagogicznym wyczuciem. Powinno być czymś oczywistym, że musimy wystrzegać się taniego eklektyzmu, oportunistycznego synkretyzmu lub snobistycznych zapożyczeń. Inkulturacja bowiem nie odnosi się tylko do form zewnętrznych, lecz dotyka istoty liturgii oraz wrażliwości wspólnoty chrześcijańskiej.

Aurelio García zauważa:

Celem adaptacji i inkulturacji liturgicznej proponowanej przez reformę liturgiczną jest uczynić liturgię żywą: aby wierni żyli tajemnicą Chrystusa i aby liturgia była żywa. Z tego powodu należy przezwyciężyć napięcie istniejące pomiędzy immobilizmem, sztywną jednolitością liturgiczną, rutynową celebracją skoncentrowaną na formach zewnętrznych, bez odniesienia do życia, a ciągłymi zmianami i brakiem jakiejkolwiek stałości, co dezorientuje wiernych i sprawia, że liturgia pozbawiona jest odniesień uniwersalnych i eklezjalnych. Pomiędzy tymi dwoma skrajnościami sytuuje się wierność Duchowi i wskazówkom Soboru Watykańskiego II, co przejawia się poszukiwaniem dróg ku pełnemu, świadomemu i czynnemu uczestnictwu wiernych w obrzędach liturgicznych ${ }^{57}$.

\footnotetext{
56 Por. VL 46-5I.

57 A. García, Celebrar la fe en el canto litúrgico, „Phase” 22I (I997) 379.
} 
Wyzwanie, jakim jest inkulturacja, wymaga zatem jednocześnie odwagi i roztropności. Ważne jest, aby roztropność nie przystopowała inicjatyw, a odwaga nie doprowadziła do zanegowania wielowiekowej mądrości Kościoła. Warto przytoczyć na zkończenie słowa abpa Annibale Bugniniego:

Gdy już zostanie zakończona publikacja ksiąg liturgicznych, każda konferencja powinna dokładnie przeanalizować obrzędy: niektóre z nich w pełni będą odpowiadać lokalnym potrzebom, zarówno pod względem formuł jak i struktury; w przypadku innych dostrzeżone zostaną pewne braki; jeszcze inne kontrastować będą ze zwyczajami własnego narodu, których nie można porzucić.

$\mathrm{Na}$ tym etapie rozpoczyna się praca ekspertów, grup studyjnych i komisji: osób wskazanych i podporząakowanych komisjom i konferencjom episkopatu, które powinny ustalić, jaki punkt i co powinnno zostać zmienione. Wtedy to, pod czujnym okiem Konferencji Episkopatu, po dokonaniu koniecznych studiów, przeprowadzi się konieczne próby i eksperymenty.

Konferencja przedstawi Rzymowi odpowiednią propozycję i skieruje prośbę do Kongregacji o aprobatę i tylko wtedy wprowadzony element przynależeć będzie do liturgicznego patrymonium lokalnego Kościoła. W pracy tej pomagać będziemy ze wszystkich naszych sił, jednakże oczywiste jest, że największy wysiłek spoczywać będzie na komisjach diecezjalnych i regionalnych.

Jak długo będzie trwał ten proces? Być może dziwnie zabrzmią te słowa..., ale praca ta nigdy nie może się zakończyć. Tylko wtedy będziemy wierni temu, do czego zobowiązał nas papież Paweł VI: sprawić, aby liturgia cieszyła się wieczną młodością̧

${ }_{58}$ Zob. A. Bugnini, Dieci anni, „Notitiae” 9 (1973), s. 395-399, oraz A. Bugnini, La reforma liturgica conquista la Chiesa, „Notitiae” Io (1974), s. I2. Por. C. Braga, Adaptación en la Liturgia, „Medellín” I (1975), s. 52-53. 


\section{SUMMARY}

\section{Liturgical use of the Andean aguayo}

In the Andean world, a piece of cloth is more than clothing: it is a communication system, and constitutes one of the most aesthetic and developed expressions. For thousands of years different ethnic groups worked with raw materials, colours and forms, creating various styles of visual art, which have generated veritable languages that have portrayed their identities and established their differences. Cloth fabrics form part of Andean peoples' development, because their features contemplate many mysteries that appear gradually. From remote times until today, cloth fabrics are present at all critical moments of the life cycle. They fulfill a conservative function that creates identity and involves multiple uses, according to the needs of each place. The more prominent activities where typical Andean cloth (called aguayo) is used include: the transport of foodstuffs, looking after children, as clothing, at festivities, and in the acts of worship of traditional Andean religion.

Considering that liturgy is one of the privileged areas for inculturation, this article poses the question of the benefit of the aguayo's use in liturgical celebrations. Firstly we present Magisterial documents of the Catholic Church on the inculturation of liturgical vestments. Secondly, we present the aguayo and its use in Andean culture, with the aim of describing its identity and social use in different contexts. Lastly, we present arguments for and against the use of the aguayo in Catholic liturgy, based on the research and opinions of the experts (anthropologists, art historians and indigenous peoples).

\section{Uso litúrgico del aguayo andino}

En el mundo andino el tejido es más que una vestimenta: es un sistema de comunicación y constituye una de las expresiones más estéticas y desarrolladas. Durante miles de años los diferentes grupos étnicos trabajaron sobre las materias primas, los colores y las formas, creando variados estilos plásticos, que llegaron a generar verdaderos lenguajes a través de los cuales los pueblos dibujaron sus identidades y edificaron sus diferencias. Los tejidos forman parte del desarrollo de los pueblos andinos porque sus características contemplan muchos misterios que aparecen paulatinamente. Desde tiempos remotos hasta hoy día los tejidos están presentes en todos momentos críticos del ciclo vital, desempeñan una función conservadora que crea identidad y involucran múltiples usos de acuerdo a las necesidades de cada lugar. Entre las más sobresalien- 
tes actividades donde aparece el uso del típico tejido andino llamado aguayo son: el transporte de alimentos, cuidado de hijos, como prenda de vestir, en la fiesta y en la actividad cultual de la tradicional religión andina.

Considerando que la liturgia constituye uno de los sectores privilegiados para la inculturación, en el artículo viene planteada la cuestión de la conveniencia de uso del aguayo en las celebraciones litúrgicas. En primer lugar se ofrece la documentación del Magisterio de la Iglesia Católica referida al tema de la inculturación de los vestimentos litúrgicos (I). Posteriormente se hace la presentación del aguayo y su uso en la cultura andina. El objetivo de esta parte es describir la identidad y uso social del aguayo presentando las características de este tejido desde sus distintos contextos de uso (2). Finalmente, en la tercera parte, fundamentando la investigación en las opiniones de los expertos (antropólogos, historiadores del arte, teólogos y la gente originaria del lugar), se presentan los argumentos pros y contras del uso del aguayo en la liturgia católica (3). 
4. Uniwersytet Papieski

If: Ji: Jana Pawła II 